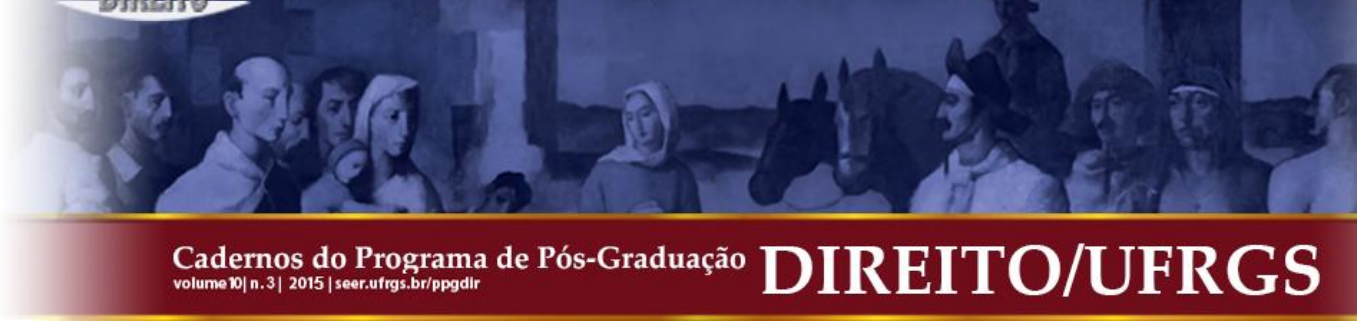

\title{
LIBERDADE DE CONCORRÊNCIA NA UNIÃO EUROPEIA: CONVERGÊNCIA DA DOUTRINA E DA JURISPRUDÊNCIA NO RECONHECIMENTO DA DISCIPLINA CONCORRENCIAL COMO BASE PARA O MERCADO INTERNO
}

\author{
FREEDOM OF COMPETITION IN THE EUROPEAN UNION: CONVERGENCE OF THE
}

DOCTRINE AND THE CASE LAW IN THE RECOGNITION OF COMPETITION LAW AS A

BASIS TO THE INTERNAL MARKET

Nicole Rinaldi de Barcellos*

\begin{abstract}
RESUMO: O objetivo deste estudo é investigar o papel da liberdade de concorrência no mercado interno da União Europeia, mediante análise doutrinária e jurisprudencial. A disciplina concorrencial compõe os instrumentos fundacionais do referido bloco econômico desde as primeiras versões até o presente momento, mantendo uma considerável estabilidade ao longo do tempo. A aplicação do direito da concorrência, por sua vez, encontra-se em constante aprimoramento, sendo objeto de discussão constante no âmbito do Tribunal de Luxemburgo, conforme os objetivos integracionistas são alargados, estimulando o desenvolvimento econômico equilibrado dos atores no mercado interno. Para desenvolver os objetivos propostos, a pesquisa foi dividida em duas partes. Na primeira seção são abordados os principais fundamentos teóricos da liberdade de concorrência no âmbito da União Europeia. Na segunda parte são apresentados casos jurisprudenciais considerados relevantes na consolidação da liberdade de concorrência como base ao mercado interno. Por fim, é destacada a essencialidade da liberdade concorrencial no processo de integração da União Europeia ao garantir e amparar as demais liberdades econômicas.
\end{abstract}

PALAVRAS-CHAVE: Direito Internacional da Concorrência. União Europeia. Liberdade de Concorrência. Mercado Interno. Tribunal de Justiça da União Europeia.
ABSTRACT: The purpose of this study is to investigate the role of freedom of competition in the European Union internal market based on doctrinal and case law analysis. Competition law composes the founding instruments of the European Union since its first versions to the present moment, maintaining a considerable stability over time. Application of competition law, however, is in constant improvement by the Luxembourg Court as integrationist goals are extended, in order to stimulate balanced economic development to the actors in the internal market. To develop the proposed objectives, the research is divided into two parts. The first section examines the main theoretical foundations of the freedom of competition within the European Union. In the second part it is presented a case law summary, considered relevant to the consolidation of the subject. Ultimately, it is highlighted that freedom of competition is substantial to the European Union process of integration by ensuring and supporting the other essential economic freedoms.

KEYWORDS: International Competition Law. European Union. Freedom of Competition. Internal Market. Court of Justice of the European Union.

SUMÁRIO: Introdução. 1 Fundamentos doutrinários da liberdade de concorrência no ordenamento jurídico da União Europeia. 1.1 Características estruturais da liberdade de concorrência na União Europeia. 1.2 Domínio de Aplicação da Liberdade Concorrencial na União Europeia. 2 Contribuição da jurisprudência do Tribunal de Luxemburgo para a consolidação da liberdade de concorrência. 2.1 Caso Dióxido de Titânio como marco jurisprudencial (C-300/89). 2.2 Casos TeliaSonera (C-52/09) e Comissão c. Italia (C-496/09). Considerações finais. Referências.

\section{INTRODUÇÃO}

A União Europeia possui como finalidade a criação de um espaço interno economicamente ampliado, com especial empenho na realização de uma integração profunda

\footnotetext{
* Mestranda no Programa de Pós-Graduação em Direito na Universidade Federal do Rio Grande do Sul (UFRGS), na linha de pesquisa Fundamentos da Integração Jurídica. Bolsista da CAPES/UFRGS. Especialista em Direito Internacional Público e Privado, e Direito da Integração pela Universidade Federal do Rio Grande do Sul (UFRGS). Graduada pela Pontifícia Universidade Católica do Rio Grande do Sul (PUCRS).
} 


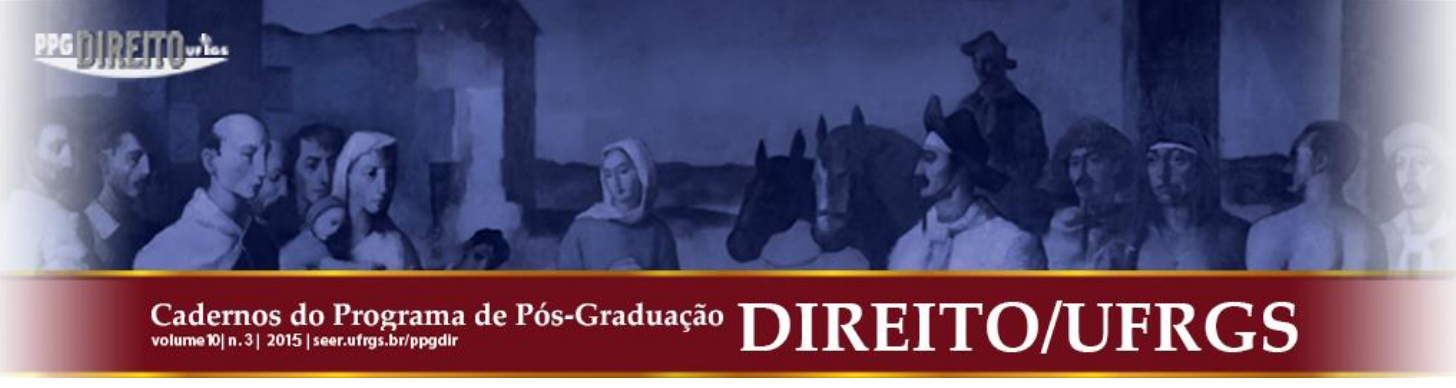

mediante seus instrumentos fundacionais. Conforme dispõe Roberto Ruiz Díaz Labrano, a evolução desse processo de integração deve ocorrer por meio de ações acordadas livremente pelos Estados, afetando setores sociais, econômicos, políticos e jurídicos, mediante bases estabelecidas com grande responsabilidade ${ }^{1}$.

As mencionadas bases são os Tratados de integração, que têm como ponto central a expansão dos intercâmbios comerciais e a circulação das pessoas entre os Estados-membros, respeitando-se as regras de liberdades econômicas expostas em seu bojo como pressupostos fundamentais do mercado interno² ${ }^{2}$ Nesse âmbito, são identificadas na União Europeia cinco liberdades econômicas fundamentais: as liberdades de circulação de mercadorias, de pessoas, de serviços, de capitais e a liberdade de concorrência, conforme teoria adotada por este estudo ${ }^{3}$. No ponto é importante destacar que a doutrina clássica defende a existência de apenas quatro liberdades, entretanto, a liberdade de concorrência encontra-se elevada ao seleto rol quando consideradas as características da sua relação com o mercado interno no direito da União Europeia.

Cada uma das liberdades econômicas fundamentais somente poderá ser realizada se acompanhada das outras, por interferir não somente nos objetivos econômicos e sociais imediatos, mas, a longo prazo, por promover a unificação dos países nos processos de integração ${ }^{4}$. No que tange à liberdade concorrencial, o legislador europeu estabeleceu um quadro jurídico único que pode ser aplicado em toda a União Europeia, destinado à proteção do consumidor no tocante às vantagens com que se beneficia no mercado interno, ao impedir que tanto as empresas, como os governos, adotem comportamentos lesivos à concorrência 5 .

As regras da concorrência fazem parte dos tratados constitutivos da União Europeia desde a sua primeira versão até o Tratado de Lisboa, mantendo uma considerável estabilidade

\footnotetext{
${ }^{1}$ RUÍZ DÍAZ LABRANO, Ricardo. La integración y las constituiciones nacionales de los Estados Parte del Mercosur. Anuario de Derecho Constitucional Latinoamericano: Edición 1999. Buenos Aires: Ciedla, KonradAdenauer-Stiftung, 1999, p. 65-78.

${ }^{2}$ BERTONI, Liliana. La Libre Circulación y los Derechos Fundamentales en los Procesos de Integración Regional. In: MOLINA DEL POZO, Carlos (Coord.). Evolución histórica y jurídica de los procesos de integración en la Unión Europea y en el Mercosur. Buenos Aires: Eudeba, 2011, p. 99.

${ }^{3}$ Sobre a liberdade de concorrência como quinta liberdade econômica fundamental na União Europeia destaca-se a obra do doutrinador Augusto Jaeger Junior. Salienta-se que a doutrina clássica entende por liberdades econômicas a livre circulação de bens, pessoas, serviços e capitais. Ver: JAEGER JUNIOR, Augusto. Liberdade de concorrência na União Européia e no Mercosul. São Paulo: LTr, 2006, 807 p.; Id. Mercados Comum e Interno e Liberdades Econômicas Fundamentais. Curitiba: Juruá, 2010, 800 p.

${ }^{4}$ ALVES, Jorge de Jesus Ferreira. Lições de Direito Comunitário. Coimbra: Coimbra Editora, 1989, p. 256.

5 JAEGER JUNIOR, Augusto. Direito Internacional da Concorrência: entre perspectivas unilaterais, bilaterais, multilaterais e regionais. Curitiba: Juruá, 2008, p. 296.
} 


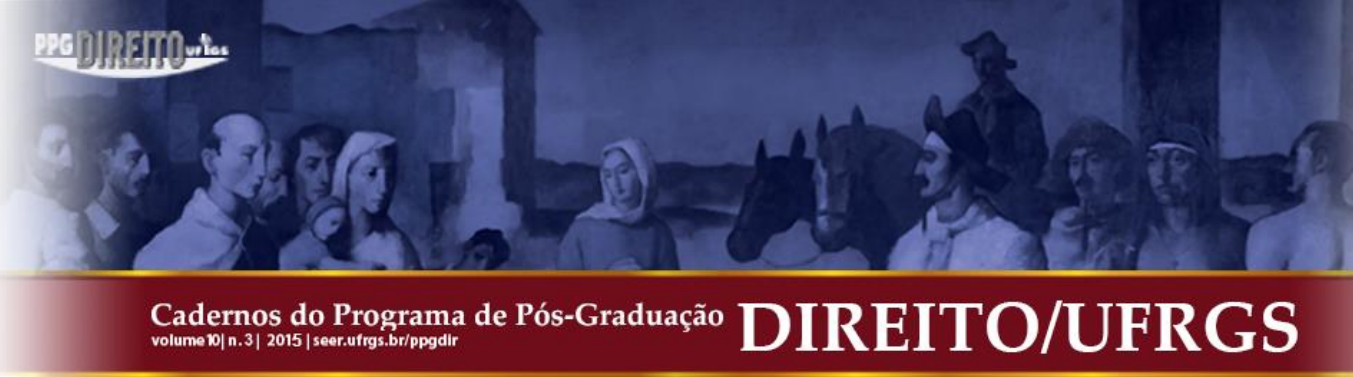

ao longo dos anos ${ }^{6}$. Por outro lado, a aplicação dessas regras encontra-se em evolução constante como objeto de discussão sobretudo no âmbito do Tribunal da Justiça da União Europeia, conforme os objetivos integracionistas são alargados, no intuito de estimular o desenvolvimento econômico equilibrado dos atores no mercado interno?

O presente artigo concentra-se na busca por respostas à seguinte questão: segundo a doutrina brasileira e estrangeira sobre integração regional e direito da concorrência, e a jurisprudência do Tribunal de Justiça da União Europeia, qual a relação entre a liberdade de concorrência e o mercado interno na União Europeia? O estudo centra-se na delimitação do papel desta liberdade no mercado interno da União Europeia, tomando-se como marco teórico a doutrina que reconhece à liberdade de concorrência o caráter de liberdade econômica fundamental na União Europeia ${ }^{8}$. Aproveita-se para fazer um recorte negativo no tema abordado, porquanto não serão referidas com profundidade as regras de condutas destinadas à proteção da concorrência, mas será privilegiado o sistema concorrencial da União Europeia.

Para desenvolver os objetivos propostos, a pesquisa foi dividida em duas partes. Na primeira seção são abordados os principais fundamentos teóricos da liberdade de concorrência no âmbito da União Europeia, na delimitação dos conceitos básicos e das características estruturais, bem como, do domínio de aplicação do controle concorrencial no âmbito do bloco. $\mathrm{Na}$ segunda seção são apresentados casos jurisprudenciais considerados interessantes na definição do papel da liberdade de concorrência em relação ao mercado interno.

Por fim, salienta-se que há muito tempo a União Europeia transfere a outros continentes conhecimentos e experiências, no âmbito do direito ou em outras áreas, mediante um "processo de circulação de modelos" ". Extrai-se, então, a importância do estudo do tema, tendo em vista que o processo de integração europeu é exemplo para os demais blocos econômicos, pois consiste no modelo de maior profundidade visto até então, de modo que a observação da sua experiência integracionista (jamais a transposição do seu modelo), seja ela positiva ou negativa, pode conduzir a alternativas viáveis aos blocos que intencionem qualquer tipo de integração econômica.

\footnotetext{
${ }^{6}$ COMISSÃO EUROPEIA. Directorate General for Competition Management Plan 2012. Bruxelas, 2011.

${ }^{7}$ SCHULTES, Marcelo. O Controle Concorrencial: Regulador do Mercado Interno na União Europeia. Cadernos do Programa de Pós-Graduação em Direito da UFRGS. Porto Alegre, v. 9, n. 1, 2014, p. 3.

${ }^{8}$ Sobre a liberdade de concorrência como quinta liberdade econômica fundamental na União Europeia, ver: JAEGER JUNIOR, Liberdade de concorrência na União Européia e no Mercosul, 800 p.

${ }^{9}$ Id. Metodologia jurídica europeia e mercosulista: considerações fundamentais. Revista da Secretaria do Tribunal Permanente de Revisão do Mercosul. Assunção, n. 3, mar. 2014, p. 119. 


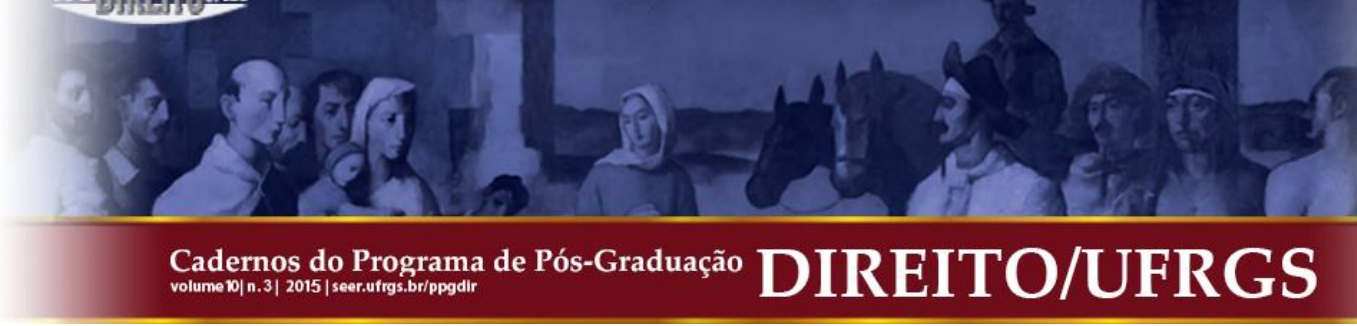

\section{FUNDAMENTOS DOUTRINÁRIOS DA LIBERDADE DE CONCORRÊNCIA NO ORDENAMENTO JURÍDICO DA UNIÃO EUROPEIA}

\subsection{Características estruturais da liberdade de concorrência na União Europeia}

Caso seja tomado por consideração um ponto de vista puramente econômico, o objetivo da integração dos mercados de diversos países funda-se na possibilidade de conceder aos indivíduos dele integrantes maiores possibilidades de escolha, mediante a oferta de uma ampla gama de produtos a menores preços ${ }^{10}$. Entretanto, pode-se dizer que existe no processo de integração da União Europeia características específicas que a tornam um mecanismo sui generis, pois almeja a promoção de uma integração que ultrapassa os fins econômicos, com base em um processo dinâmico de harmonização das práticas nos sistemas nacionais para permitir a formação de um verdadeiro mercado único sem barreiras internas ${ }^{11}$.

Todas as regras e políticas que possuem como finalidade auxiliar na realização do mercado interno na União Europeia são classificadas como regras a ele apoiadoras ${ }^{12}$, como a promoção da livre concorrência, que deve permear as relações econômicas a serem concretizadas no processo de integração. Nesse aspecto, são destacados dois distintos objetivos perseguidos pelas legislações da concorrência de países ou regiões, que são denominados gerais ou integracionistas, conforme dispõe Ricardo Thomasinho da Cunha, de modo que "os primeiros estão presentes em qualquer lei de defesa da competição e os segundos somente existem em um processo de integração econômica, funcionando como instrumento auxiliar da união"13.

Isso significa dizer que em um processo de integração econômica, a legislação concorrencial possui a finalidade de instrumento formador do espaço único ou do mercado interno, como é o caso da União Europeia. Ocorre, entretanto, que esta é uma "via de mão

\footnotetext{
10 AYRAL, Michel. Le marché intérieur de l'Union européenne: Les règles du jeu. Paris: Le documentation française, 1998, p. 7.

${ }^{11}$ Segundo dispõe Michel Ayral: “(...) Il y a cependant, dans le mécanisme d'integratión de la communauté, des particularités qui en font un mécanism sui generis". Ibid., p. 7.

12 JAEGER JUNIOR, Liberdade de concorrência na União Europeia e no Mercosul, p. 238.

${ }^{13}$ CUNHA, Ricardo Thomasinho da. Direito e Defesa da Concorrência: Mercosul e União Europeia. Barueri: Manole, 2003. p. 24.
}

Cadernos do Programa de Pós-Graduação em Direito PPGDir./UFRgS | Edição Digital | Porto Alegre | Volume X | Número 3 | 2015 | P. 224 - 252 


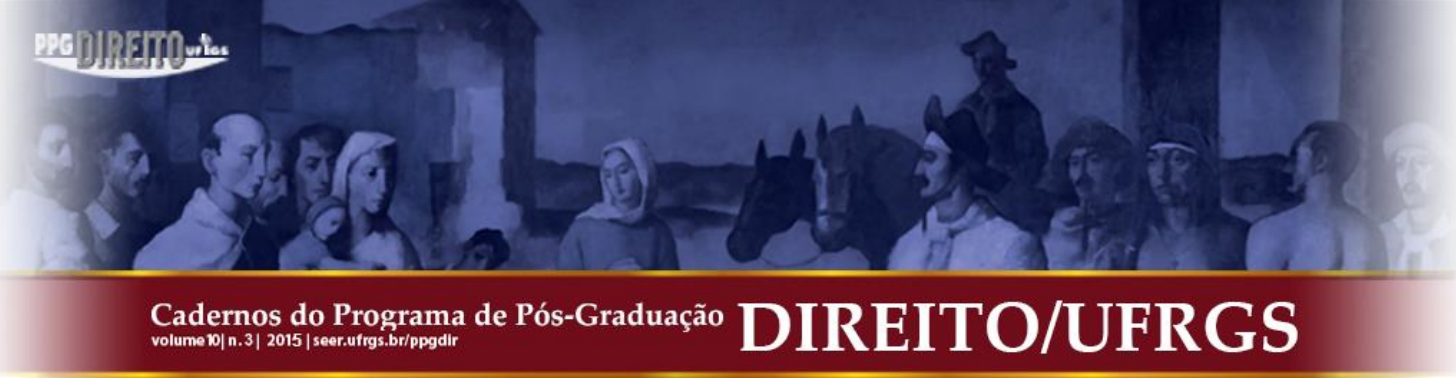

dupla"14, porquanto a instauração de um livre mercado entre os Estados-membros é pressuposto fundamental na obtenção de vantagens concorrenciais, porém, a concorrência apenas se instala onde existir o livre mercado ${ }^{15}$. Somente mediante a perda das proteções estatais é criada a concorrência entre as empresas, expondo os integrantes de um mercado a ela ${ }^{16}$, o que resulta na adoção de práticas pelas empresas que são próprias para a manutenção dos mercados, como cartéis, ou as práticas dos Estados para a proteção das empresas, como os auxílios públicos.

As normas destinadas à regulação destes fenômenos possuem como objeto a garantia da concorrência, no intuito de impedir que os agentes econômicos ajam em detrimento do mercado, e, principalmente, para permitir a formação de um mercado interno onde estes possam agir ${ }^{17}$. As consequências para esse fenômeno são o aumento nos ganhos de eficiência das empresas, o surgimento de novos padrões de concorrência, a inovação empresarial e a multiplicação de novos processos negociais ${ }^{18}$.

Diante disso, inicialmente, é importante analisar o conceito de direito da concorrência, de modo que o seu papel possa ser definido perante o ordenamento jurídico da União Europeia. A concorrência, como fundamento da economia de mercado, é a grande impulsionadora da competição existente entre os agentes atuantes em um mesmo mercado, fazendo com que coexistam de forma sadia, na busca pelo consumidor ${ }^{19}$. Nesse âmbito, o direito da concorrência fornece o "aparato necessário para manter esta disputa em níveis razoáveis, impedindo, assim, o desenvolvimento da denominada concorrência predatória"20.

Segundo Gesner Oliveira e João Grandino Rodas, “o direito da concorrência é o conjunto de regras jurídicas destinadas a apurar, reprimir e prevenir as várias modalidades de abuso do poder econômico" 21 , favorecendo-se a livre iniciativa, em favor da coletividade. A regulação da concorrência, então, possui inspiração liberal, ao ser baseada no dinamismo da

\footnotetext{
${ }^{14}$ JAEGER JUNIOR, Direito Internacional da Concorrência, p. 285.

15 HOEKMAN, Bernard; MAVROIDIS, Petors C. Economic development, competition policy and WTO. Washington DC: Banco Mundial, 2002, p. 4.

${ }^{16}$ GOODE, W. Dictionary of Trade Policy Terms. 4. ed. 2003. Disponível em: <http://ctrc.sice.oas.org/trc/WTO /Documents/Dictionary\%20of\%20trade\%20\%20policy\%20terms.pdf $>$. Acesso em: 15 jan. 2015.

${ }^{17}$ EVENETT, Simon. Merger and anti-cartel policies in an era of integrating markets. In: HOEKMAN, B.; MATTOO, A.; ENGLISH, P. (Ed.). Development, Trade and WTO: a handbook. Washington DC: Banco Mundial, 2002, p. 456-462.

${ }^{18}$ JAEGER JUNIOR, Direito Internacional da Concorrência, p. 286.

${ }^{19}$ MARQUES, Frederico do Valle Magalhães. Direito Internacional da Concorrência. Rio de Janeiro: Renovar, 2006, p. 108.

${ }^{20}$ Ibid., p. 108.

${ }^{21}$ OLIVEIRA, Gesner; RODAS, João Grandino. Direito e economia da concorrência. 2. ed. rev. e atual. São Paulo: Revista dos Tribunais, 2013, p. 44.
} 


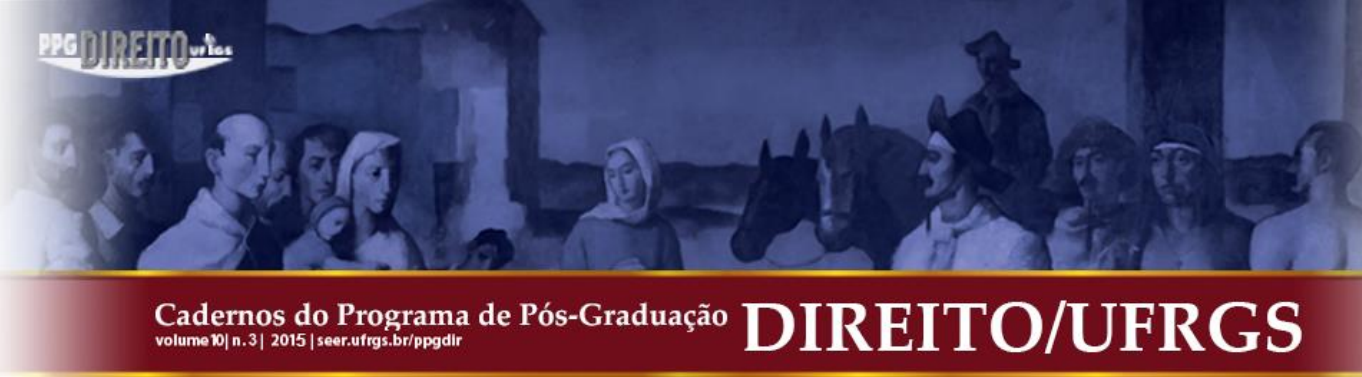

iniciativa privada e no jogo das forças do mercado ${ }^{22}$. Trata-se de uma ordem pública, pois protege um bem jurídico de interesse público, que é o mercado ${ }^{23}$.

Sob esse prisma, Jorge de Jesus Ferreira Alves salienta que existem três modelos econômicos segundo os quais é possível a definição da concorrência: o primeiro visa à maior liberdade de ação das empresas e à maior liberdade de ação dos consumidores; o segundo tem interesse na proteção e reconstituição de uma concorrência pura e perfeita; e o terceiro, por outro lado, não corrobora a tese da concorrência pura e perfeita, devendo esta ser vista de forma evolutiva e aberta a adaptações ${ }^{24}$.

No âmbito do direito da União Europeia, tanto o Tratado da União Europeia, como o Tratado sobre o Funcionamento da União Europeia, silenciam sobre o modelo de concorrência que pretendem preservar. Segundo João Mota de Campos, entretanto, a análise das disposições dos Tratados e da jurisprudência do Tribunal de Justiça da União Europeia permite concluir que estes almejam assegurar uma "concorrência praticável", ou seja, o direito da concorrência no âmbito da União Europeia protege uma competição efetiva e eficaz no quadro de um mercado comunitário tradicionalmente pouco concorrencial ${ }^{25}$.

O interesse da disciplina da concorrência na União Europeia para a preservação de uma concorrência praticável possui um regime operado no intuito de preservar a liberdade de “concorrência entre os desiguais" ${ }^{26}$, em razão das assimetrias encontradas entre os agentes sob a égide do liberalismo econômico ${ }^{27}$. Cuida-se da segurança de acesso ao mercado para um número suficiente de empresas independentes funcionando em condições adequadas, de forma a proporcionar aos consumidores e utilizadores uma razoável possibilidade de escolha ${ }^{28}$.

Na União Europeia, a concorrência adota a função de instrumento para a obtenção do equilíbrio econômico ${ }^{29}$, à medida que se molda para as finalidades da União. Desse modo, ela

\footnotetext{
22 FRISON-ROCHE, Marie; PAYET, Marie-Stéphane. Droit de la concurrence. Paris: Dalloz, 2006, p. 8-11.

23 JAEGER JUNIOR, op. cit., p. 290.

${ }^{24}$ ALVES, Jorge de Jesus Ferreira. Direito da Concorrência nas Comunidades Europeias. 2. ed. Coimbra: Coimbra Editora, 1992, p. 65.

${ }^{25}$ CAMPOS, Manual de Direito Comunitário, p. 436; Sobre concorrência praticável, ver: FRISON-ROCHE; PAYET, Droit de la concurrence, p. 33-34.

26 DROMI, Roberto; EKMEKDJIAN, Miguel A.; RIVERA, Julio C. Derecho comunitario: sistemas de integracion, regimen del Mercosul. 2. ed. Buenos Aires: Ciudad Argentina, 1996, p. 337.

${ }^{27}$ CELLI JUNIOR, Umberto. Regras de concorrência no Direito Internacional moderno. Porto Alegre: Livraria do Advogado, 1998, p. 55-57.

${ }^{28}$ CAMPOS, op. cit., p. 436.

29 NUSDEO, Ana Maria de Oliveira. Defesa da Concorrência e Globalização Econômica: o controle da concentração de empresas. São Paulo: Malheiros, 2002, p. 98. 


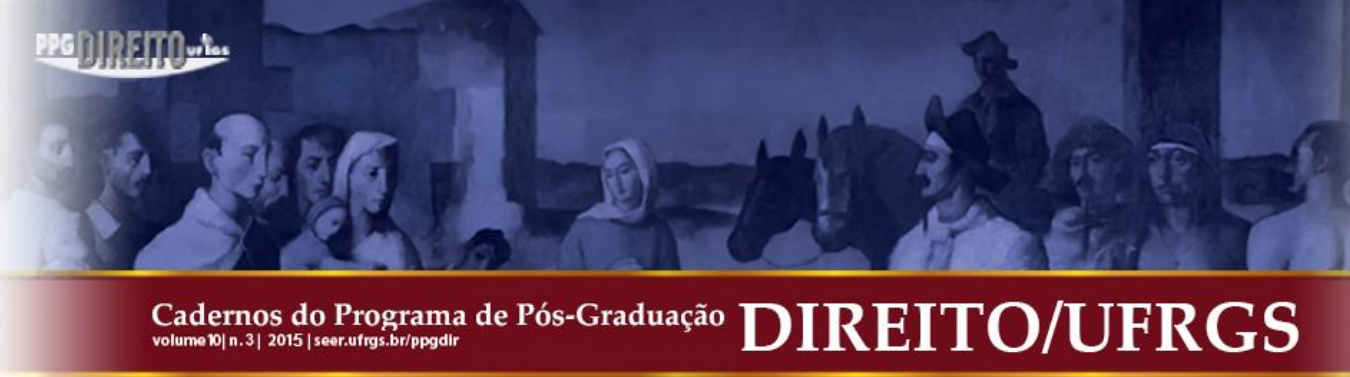

será derrogada nos casos em que uma prática anticoncorrencial contribuir em maior grau que a própria concorrência para o desenvolvimento econômico ou para o progresso social ${ }^{30}$.

O sistema de legislação da concorrência adotado pela União Europeia é classificado como misto ou híbrido, pois mescla os sistemas da ilicitude e do abuso ${ }^{31}$. Desse modo, a legislação vigente prevê que certas práticas necessitam de autorização dos órgãos competentes na União, enquanto em outras, a regulação é feita a posteriori, punitivamente ${ }^{32}$.

Considerando-se as características estruturais da concorrência na União Europeia, é possível dizer que a sua proteção ultrapassa a classificação de política comunitária, alcançando o patamar de liberdade fundamental ${ }^{33}$. Isto porque um dos objetivos dos Tratados da União é a criação e a manutenção do mercado interno, que inexistiria caso não fosse permeado pela liberdade de concorrência, e sem a qual as outras liberdades de circulação citadas pela doutrina clássica não existiriam ${ }^{34}$, tampouco possuiriam efeito.

O doutrinador João Mota de Campos dispõe que o mercado interno é uma realidade que corresponde a um grau superior de integração econômica, segundo o qual não é necessária apenas a liberdade de circulação de mercadorias, mas também são essenciais as outras três liberdades econômicas fundamentais ${ }^{35}$. Acrescenta-se a elas, segundo Augusto Jaeger Junior, a liberdade de concorrência, pois esta exerce um papel central no mercado interno, que, criado pelas liberdades econômicas, necessita do direito concorrencial para a proteção e para a garantia das atividades às quais foi destinado, protegendo essas liberdades fundamentais de limitações impostas por comportamentos contrários à concorrência ${ }^{36}$.

Veja-se que a partir das reformas dos tratados no tocante ao direito da concorrência, este foi se aproximando, ao longo do tempo, ao sistema das liberdades econômicas fundamentais, conforme a modificação da estrutura jurídica da União Europeia, em constante evolução e com contornos finais ainda indefinidos ${ }^{37}$. Inicialmente, antes da formação do mercado interno na

\footnotetext{
${ }^{30}$ JAEGER JUNIOR, Direito Internacional da Concorrência, p. 292.

${ }^{31}$ CAMPELLO, Dyle. O direito da concorrência no direito comunitário. Rio de Janeiro: Renovar, 2001, p. 29.

32 JAEGER JUNIOR, Direito Internacional da Concorrência, p. 293.

${ }^{33}$ Sobre o tema, destaca-se a já mencionada tese de Augusto Jaeger Junior, publicada no ano de 2008: Id., Liberdade de concorrência na União Européia e no Mercosul, p. 236-266.

${ }^{34}$ Sobre as liberdades econômicas fundamentais, ver: CAMPOS, Manual de Direito Comunitário, p. 401-402; AYRAL, Le marché intérieur de l'Union européenne: Les règles du jeu, 1998, p. 25.

${ }^{35}$ CAMPOS, op. cit., p. 401-402.

${ }^{36}$ JAEGER JUNIOR, Mercados Comum e Interno e Liberdades Econômicas Fundamentais, p 223.

37 BORCHARDT, Klaus Dieter. The ABC of European Union Law. Luxembourg: Publications Office of the European Union, 2010, p. 32.
} 


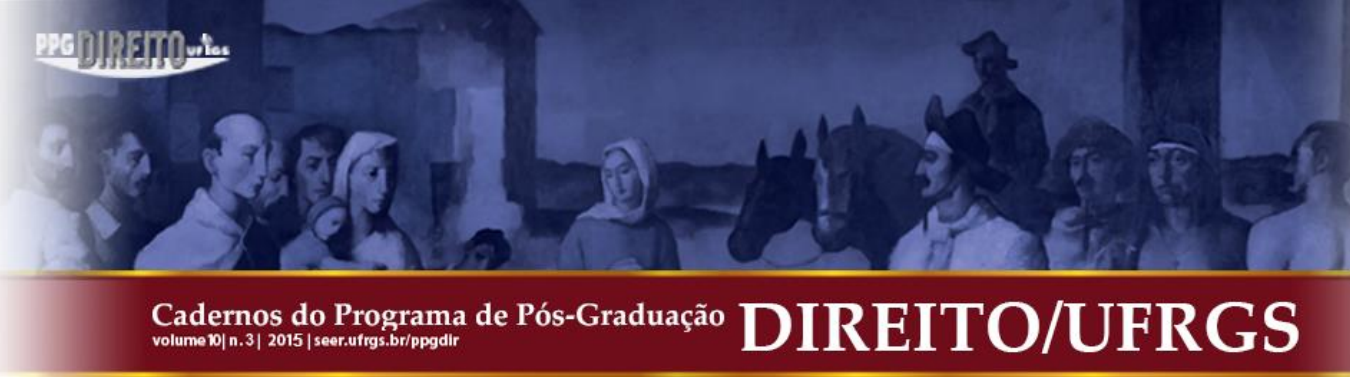

União, o objetivo final do projeto de integração da Europa era a consolidação de um mercado comum, e o seu estabelecimento não foi uma tarefa simples.

Historicamente, o termo mercado comum não encontrava conceito definido nos Tratados, sendo delimitado pelo Tribunal de Luxemburgo no caso Gaston-Schul de 1982, segundo o qual o "estabelecimento de um mercado comum visa a eliminação de todos os entraves ao comércio intracomunitário, com a finalidade da fusão dos mercados nacionais num mercado único, que seja o mais próximo possível de um mercado interior"38. Outras dificuldades encontradas durante estes anos são descritas pela doutrina, como a aceitação, pelos Estadosmembros, do princípio do país de origem, o enfrentamento de crises políticas e econômicas e a superação de insuficiências, formulando-se propostas de relançamento do projeto ${ }^{39}$. À época, a manutenção do mercado comum somente foi garantida com a conformação das liberdades econômicas fundamentais. Para tanto, a contribuição da liberdade de concorrência foi elementar.

Com o surgimento do mercado interno como objetivo, mediante o Livro Branco da Comissão de 1985 e a sua positivação pelo Ato Único Europeu em $1987^{40}$, este foi classificado como uma nova, posterior e mais ampla fase do mercado comum, sempre vinculada à ideia de maior aproximação legislativa dos Estados-membros ${ }^{41}$. Observa-se que a doutrina especializada muito dissertou sobre o status do mercado interno e sua relação com o mercado comum, mas a jurisprudência veio a aclarar as dúvidas remanescentes ${ }^{42}$.

Nesse âmbito, foi possibilitada uma nova margem à quantificação das liberdades econômicas fundamentais, elevando-se a liberdade de concorrência a uma delas, a quinta, em função dos elementos comuns que com as demais apresenta e das suas implicações junto ao mercado interno ${ }^{43}$. Destaca-se, como mencionado, que a jurisprudência do atual Tribunal de Justiça da União Europeia, mediante o caso Dióxido de Titânio de 1991, contribuiu para a alteração da classificação da liberdade de concorrência, indicando a utilização da regra

38 Caso 15/81 Gaston-Shul, EuGh, SIg. 1982. Disponível em: <http://eur-lex.europa.eu/legal-content/EN/ TXT/PDF/?uri=CELEX:61981CJ0015\& qid=1410409313332\&from=EN>. Acesso em: 15 jan. 2015.

39 JAEGER JUNIOR, Liberdade de Concorrência na União Europeia e no Mercosul, p. 731.

${ }^{40}$ No Livro Branco da Comissão aprovado em 29 de junho de 1985 pelo Conselho Europeu foi estabelecido um catálogo de medidas para a remoção de barreiras e para a melhoria da ação transfronteiriça das empresas. Ibid., p. 109-110.

${ }^{41}$ ROSSI, Lucia Serena. Il buon funzionamento del mercato comune: delimitazione dei poteri fra CEE e stati membri. Milano: Giuffrè Editore, 1990, p. 31.

42 BARENTS, René. The Internal Market Unlimited: Some Observations on the Legal Basis of Community Legislation. Common Market Law Review, Londres, n. 30, v. 1, 1993, p. 102-103.

43 JAEGER JUNIOR, op. cit., p. 732.

Cadernos do Programa de Pós-Graduação em Direito PPGDir./UFRgS | Edição Digital | Porto Alegre | Volume X | Número 3 | 2015 | P. $224-252$ 


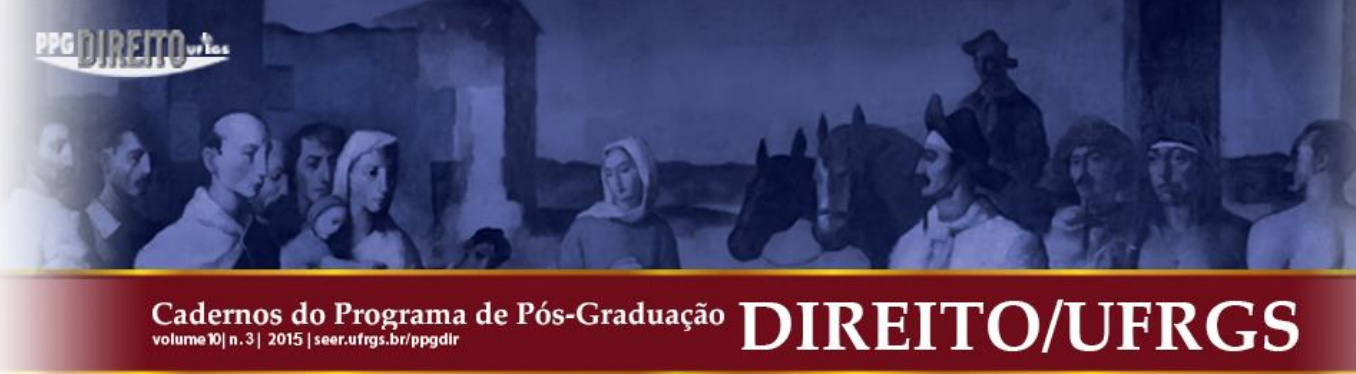

destinada ao mercado interno para a aproximação das normas que promovessem distorções na competitividade, conforme será analisado na segunda parte deste estudo.

Por fim, na esteira do defendido pelo doutrinador Augusto Jaeger Junior, é importante ressaltar que existe uma preferência à política da concorrência entre as suas originárias pares para elevação à categoria de liberdade, veja-se a impossibilidade de conformação de um mercado comum em economias planificadas diante da inexistência de um mercado livre com concorrência. Salienta-se o seu caráter transfronteiriço, que a equipara às liberdades fundamentais, e a sua aproximação ao catálogo de direitos fundamentais nos Tratados da União Europeia, como confirmação da identificação desta liberdade com as demais ${ }^{44}$.

Passa-se, então, à análise da evolução do controle concorrencial no ordenamento jurídico da União Europeia e ao estudo do seu domínio de aplicação. Será apresentada a fundamental importância da liberdade de concorrência no processo de integração entre os Estados-membros da União, com vistas ao estímulo da consolidação e manutenção do mercado interno e do seu funcionamento com máxima eficiência ${ }^{45}$.

\subsection{Domínio de Aplicação da Liberdade Concorrencial na União Europeia}

O direito comunitário da concorrência não possui longa tradição se comparado a outros sistemas, tendo adquirido ao longo de seu desenvolvimento características próprias que acompanham o dinamismo da estrutura normativa da União Europeia ${ }^{46}$. Os Estados europeus que formam o bloco econômico não dispunham de legislações concorrenciais próprias até o princípio do século XX, quando somente a Alemanha possuía uma legislação antitruste, datada de $1923^{47}$. Os demais países condenavam a prática de atos anticoncorrenciais mediante institutos tradicionais do direito, de modo que somente depois da Segunda Guerra Mundial a adoção de regras de concorrência ganhasse destaque ${ }^{48}$.

Com a criação da Comunidade Europeia, pelo Tratado de Roma de 1957, foram estabelecidos os artigos 81 a 89 do Tratado das Comunidades Europeias, atuais artigos 101 a 109 do Tratado Sobre o Funcionamento da União Europeia (TFUE), que constituem, ainda hoje,

\footnotetext{
${ }^{44}$ JAEGER JUNIOR, Mercados Comum e Interno e Liberdades Econômicas Fundamentais, p 225-228.

${ }^{45}$ CELLI JUNIOR, Regras de concorrência no Direito Internacional moderno, p. 62.

${ }^{46}$ PESCATORE, Pierre. Derecho de la integración: nuevo fenómeno en las relaciones internacionales. Buenos Aires: Intal, 1973; JAEGER JUNIOR, Direito Internacional da Concorrência, p. 86.

${ }^{47}$ SILVA, Valéria Guimarães de Lima e. Direito Antitruste: Aspectos Internacionais. Curitiba: Juruá, 2006, p. 184.

${ }^{48}$ CELLI JUNIOR, op. cit., p. 51.
}

Cadernos do Programa de Pós-Graduação em Direito PPGDir./UFRgS | Edição Digital | Porto Alegre | Volume X | Número 3 | 2015 | P. 224 -252 


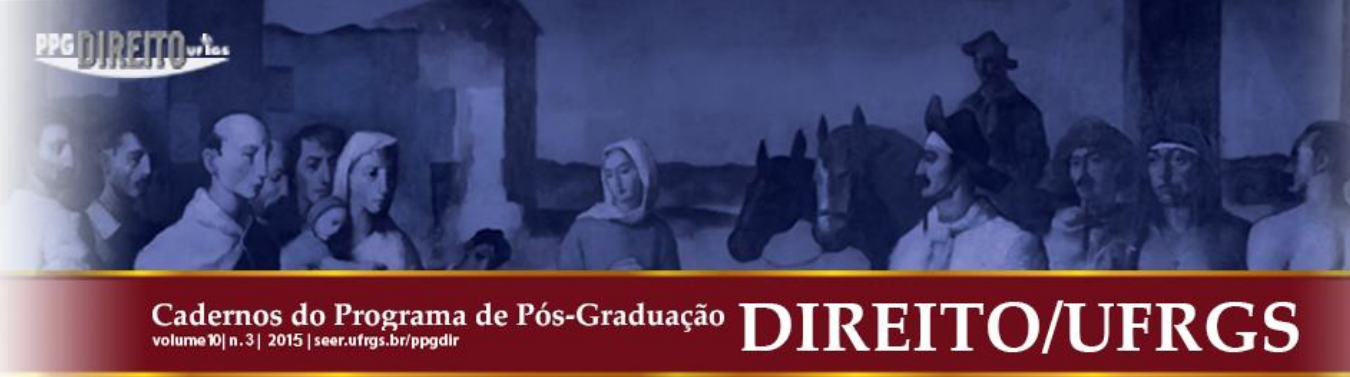

transferidas ao "Protocolo $\mathrm{n}^{\mathrm{o}}$ 27, Relativo ao Mercado Interno e à Concorrência" ${ }_{55}$, sendo, entretanto, mantida a garantia da proteção jurídica à liberdade de concorrência na União Europeia, bem como o seu status jurídico ${ }^{56}$.

O capítulo do Tratado sobre o Funcionamento da União Europeia referente à concorrência possui o condão de organizar e disciplinar o sistema concorrencial no espaço comunitário, representando, segundo Paulo Borba Casella, o núcleo da regulamentação da União Europeia na matéria ${ }^{57}$. É possível concluir, então, com base nos artigos 101 a 109 do TFUE, que a regulação da concorrência no mencionado bloco econômico ultrapassou as fronteiras nacionais e se instalou no âmbito supranacional.

O direito comunitário da concorrência encontra-se centrado em áreas bem definidas, como cartéis, abusos de posição dominante, fusões e aquisições de empresas e papel dos governos $^{58}$. Dessa forma, a legislação para o controle da manutenção da concorrência se desenvolve em duas linhas: o controle das práticas e dos acordos que deturpem a concorrência, para as empresas; e a disciplina dos recursos públicos, para os Estados-membros.

O campo de aplicação dessas normas, por sua vez, é definido em função da possibilidade de afetação do comércio e da localização das práticas restritivas da concorrência. A mencionada afetação refere-se aos comportamentos das empresas, conforme os artigos 101 e 102 do TFUE e às intervenções dos Estados, conforme o artigo 107 do TFUE, sendo condição da aplicação destas regras a suscetibilidade de o comportamento afetar o comércio ${ }^{59}$. Na verdade, esse critério funciona como um método de repartição de competências entre o governo da União Europeia e dos Estados-membros, fazendo com que o direito comunitário da concorrência seja aplicável sempre que um acordo interesse às trocas comerciais entre os Estados ${ }^{60}$. Às autoridades nacionais compete somente as práticas restritivas da concorrência cujos efeitos se manifestem no âmbito interno.

\footnotetext{
55 "Protocolo n' 27: AS ALTAS PARTES CONTRATANTES, TENDO EM CONTA que o mercado interno, tal como estabelecido no artigo 3.o do Tratado da União Europeia, inclui um sistema que assegura que a concorrência não seja falseada, ACORDARAM em que, para esse efeito, a União, se necessário, toma medidas ao abrigo do disposto nos Tratados, incluindo do artigo 352.o do Tratado sobre o Funcionamento da União Europeia”. UNIÃO EUROPEIA. Tratado da União Europeia (Versão Consolidada). Disponível em: <http://eur-lex.europa.eu/legalcontent/PT/TXT/PDF/?uri=CELEX:12012M/TXT \&from=EN>. Acesso em: 15 jan. 2015.

56 JAEGER JUNIOR, op. cit., p. 451.

${ }^{57}$ CASELLA, Paulo Borba. Comunidade europeia e seu ordenamento jurídico. São Paulo: LTr, 1994, p. 425.

${ }^{58}$ JAEGER JUNIOR, Direito Internacional da Concorrência, p. 296.

${ }^{59}$ CELLI JUNIOR, Regras de concorrência no Direito Internacional moderno, p. 66.

${ }^{60}$ CAMPOS, Manual de Direito Comunitário, p. 437.
} 


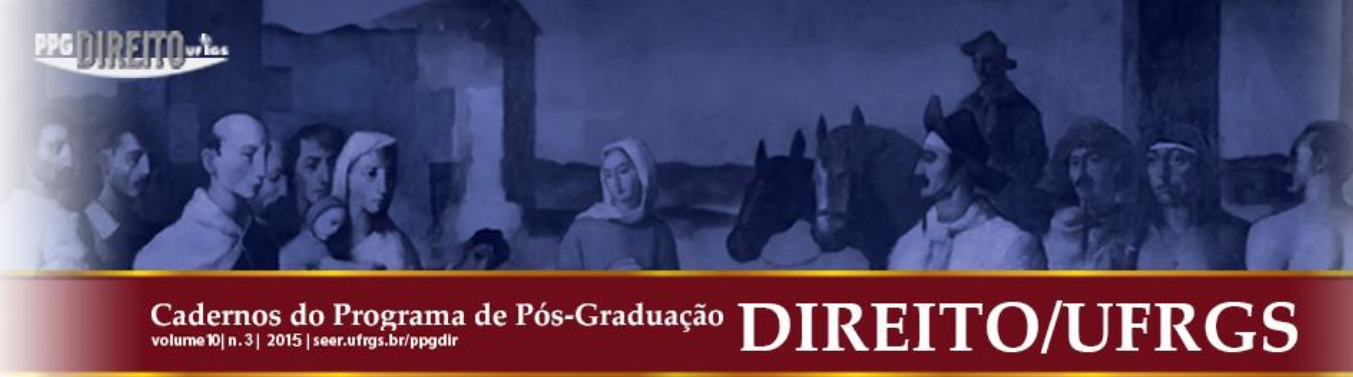

No tocante à localização do efeito anticoncorrencial, a aplicação do direito comunitário da concorrência é excluída das práticas cuja repercussão se verifique exclusivamente fora do espaço da União Europeia, como forma de expressão do efeito territorial. As regras comunitárias são aplicáveis, então, quando uma prática anticoncorrencial afete o comércio entre os Estados-membros ou quando não possa prejudicar a aplicação plena e uniforme do direito da União Europeia, sendo que, quando essa condição não for preenchida, emprega-se o direito interno. Isto porque prevalece, sempre, o princípio da primazia do direito comunitário ${ }^{61}$.

Atualmente, o aparato normativo existente no âmbito da União Europeia consiste nos artigos 101 a 106 do TFUE, com as normas do direito da concorrência aplicáveis às empresas ${ }^{62}$, e nos artigos 107 a 109 do TFUE, com as normas referentes aos auxílios concedidos pelos Estados $^{63}$. Toda a estrutura regulatória deve ser aplicada uniformemente pelas autoridades da concorrência, pela Comissão ou pelo Tribunal de Justiça da União Europeia, de modo a garantir a plena proteção da liberdade em todo o território do bloco econômico ${ }^{64}$.

Diante do exposto, apontado o domínio de aplicação das regras existentes no mercado interno da União Europeia, conclui-se que a evolução das normas de concorrência ao longo dos anos possibilitou a consecução dos objetivos integracionistas iniciais do bloco. Segundo Augusto Jaeger Junior, o mercado interno pressupõe que todos os agentes econômicos estabeleçam um regime jurídico que permita condições de concorrência iguais, de modo que "deve ser permitido que os atores encontrem regras iguais ou que as diferenças remanescentes não produzam influência sobre as duas decisões econômicas" ${ }^{65}$.

Como conclusão parcial da primeira parte deste estudo, destaca-se que a concorrência foi substantiva para a criação e para o fortalecimento do mercado interno, porquanto este não existiria sem aquela. Ademais, ainda quando os objetivos da União Europeia eram a criação do mercado comum, o direito da concorrência ocupava posição de destaque, pois desde o primeiro dia de existência da Comunidade Europeia de então foi estabelecida a necessidade de observância do não falseamento concorrencial.

\footnotetext{
${ }^{61}$ FRISON-ROCHE; PAYET, Droit de la concurrence, p. 14-15.

${ }^{62}$ Sobre o tema, ver: CRAIG, Paul; de BÚRCA, Gráinne. EU law: text, cases, and materials. 4. ed. Oxford: Oxford University Press, 2007, p. 950-1003.

${ }^{63}$ Sobre o tema, ver: JAEGER JUNIOR, Augusto; NORDMEIER, Carl Friedrich. Novidades na regulamentação das ajudas públicas do direito comunitário da concorrência. Revista de Direito da Concorrência. Brasília, n. 22, 2010, p. 11-64.

${ }^{64}$ FRISON-ROCHE; PAYET, Droit de la concurrence, p. 19.

65 JAEGER JUNIOR, Liberdade de concorrência na União Europeia e no Mercosul, p. 137.

Cadernos do Programa de Pós-Graduação em Direito PPGDir./UFRGS | Edição Digital | Porto Alegre | Volume X | Número 3 | 2015 | P. $224-252$
} 


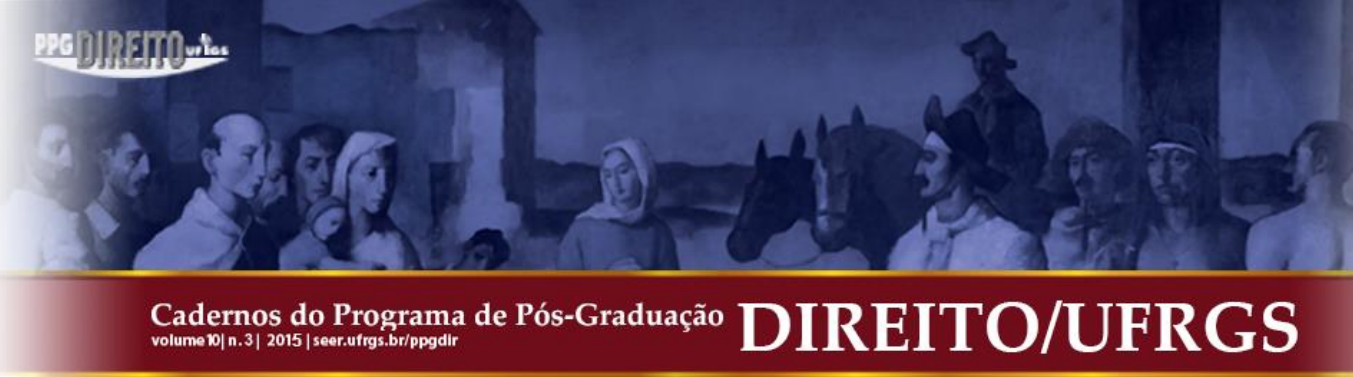

O processo de evolução das regras de concorrência possui papel fundamental na modificação das estruturas de mercado, como forma de amparar a evolução da integração europeia, contribuindo, ainda, ao aumento no nível de empregos, à inserção das pequenas empresas no processo competitivo, à proteção dos consumidores, ao equilíbrio ao comércio entre os Estados-membros e à integração do mercado comunitário ${ }^{66}$.

Segundo Carolina Pancotto Bohrer Munhoz, na "abordagem do desenvolvimento como liberdade, a concorrência tem importância independentemente da geração ou não de efeitos econômicos, justamente por garantir liberdades importantes para o processo de desenvolvimento"67. Sendo assim, insta destacar a primordial importância da liberdade concorrencial para a consecução dos objetivos da União Europeia e para a consolidação do processo de integração, reconhecendo-se o seu papel de liberdade econômica fundamental.

\section{CONTRIBUIÇÃO DA JURISPRUDÊNCIA DO TRIBUNAL DE LUXEMBURGO PARA A CONSOLIDAÇÃO DA LIBERDADE DE CONCORRÊNCIA}

\subsection{Caso Dióxido de Titânio como marco jurisprudencial (C-300/89)}

O Tribunal de Luxemburgo (Tribunal de Justiça da União Europeia), desde a sua criação, exerce papel central no reconhecimento dos princípios norteadores do direito da União Europeia, como a aplicabilidade das normas supranacionais sobre o direito interno dos Estadosmembros e a definição de conceitos abertos presentes nos seus Tratados fundacionais ${ }^{68}$. Segundo João Mota de Campos, o Tribunal é um órgão inteiramente independente das restantes instituições da União Europeia e dos governos dos Estados-membros, com jurisdição própria e competência exclusiva em determinadas matérias que aprecia em conformidade com o direito da União ${ }^{69}$.

Na esteira do disposto por Paulo Borba Casella, a jurisprudência atua na consolidação das liberdades econômicas fundamentais para o alcance do mercado interno, sendo que o Tribunal, por sua atuação, estrutura o corpus do direito unional aplicável a todos: às instituições,

\footnotetext{
${ }^{66}$ NUSDEO, Defesa da Concorrência e Globalização Econômica, p. 97-107.

${ }^{67}$ MUNHOZ, Carolina Pancotto Bohrer. Direito, livre concorrência e desenvolvimento. São Paulo: Lex Editora, 2006, p. 137.

${ }^{68}$ ALMEIDA, Elizabeth Accioly Pinto de. Mercosul e União Européia: estrutura jurídico-institucional. Curitiba: Juruá, 1996, p. 100.

${ }^{69}$ CAMPOS, Manual de Direito Comunitário, p. 149.
}

Cadernos do Programa de Pós-Graduação em Direito PPGDir./UFRgS | Edição Digital | Porto Alegre | Volume X | Número 3 | 2015 | P. $224-252$ 


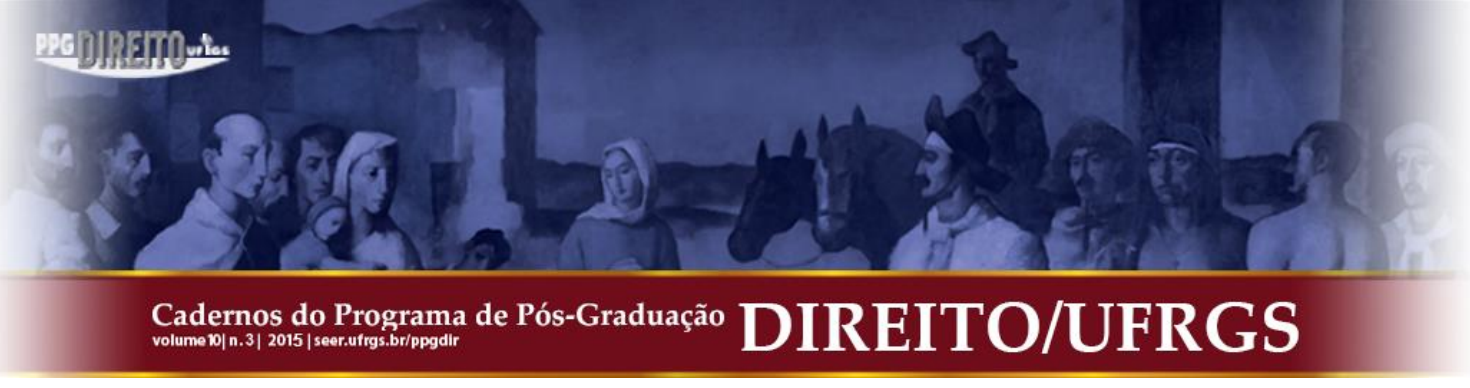

aos Estados-membros, aos tribunais nacionais e aos particulares ${ }^{70}$. Por essa razão, esta parte do estudo dedica-se à análise das decisões do Tribunal de Justiça da União Europeia, ex-Tribunal de Justiça das Comunidades Europeias, no intuito de aproximar a importância da liberdade de concorrência ao mercado interno, na condição de liberdade econômica fundamental.

Inicialmente, apresenta-se o caso Dióxido de Titânio como marco jurisprudencial, pois operou uma verdadeira revolução no entendimento dos conceitos de mercado comum e mercado interno, ao possibilitar o reconhecimento da liberdade de concorrência como tal ${ }^{71}$. Mesmo que não possuísse como finalidade uma definição conceitual, esta decisão acaba por ter demonstrado que o mercado interno abrange mais que o mercado comum.

O Ato Único Europeu de 1986, em vigor desde $1^{\circ}$ de julho de 1987, colocou em dúvida qual a extensão do mercado interno na União Europeia, ao defini-lo como um espaço sem fronteiras interiores, na qual a livre circulação das mercadorias, das pessoas, dos serviços e dos capitais fosse assegurada conforme as disposições do Tratado ${ }^{72}$. Positivado o conceito de mercado interno, a doutrina promoveu discussões acerca da inclusão da liberdade de concorrência nele, tendo em vista que esta não se encontrava especificamente nominada, tampouco era apresentado pelo Tratado um paralelo com o antigo conceito de mercado comum.

Diante da oposição de conceitos de mercado comum e mercado interno, a doutrina dispôs de três teorias: (i) da limitação, na qual o mercado interno representa menos que o mercado comum; (ii) da sinonímia, em que ambos mercados comum e interno são, em essência, correspondentes; (iii) e da ampliação, na qual o mercado interno é uma fortificação e um desenvolvimento do mercado comum ${ }^{73}$. Entende-se pela prevalência da teoria da ampliação, na qual o mercado interno corresponde à fortificação e ao desenvolvimento do mercado comum ${ }^{74}$.

É nesse aspecto que se destaca o Caso Dióxido de Titânio de $1991^{75}$, pois foi mediante ele que o ex-Tribunal de Justiça das Comunidades Europeias estabeleceu que o mercado interno abrange mais que o mercado comum. O julgamento do caso alterou a classificação da liberdade

\footnotetext{
${ }^{70}$ CASELLA, Comunidade Européia e seu ordenamento jurídico, p. 331.

${ }^{71}$ JAEGER JUNIOR, Liberdade de concorrência na União Europeia e no Mercosul, p. 220-236.

72 Texto ex-artigo 142 do TCE, atual artigo 26.2 do TFUE, in verbis: "Artigo 26.2. 2. O mercado interno compreende um espaço sem fronteiras internas no qual a livre circulação das mercadorias, das pessoas, dos serviços e dos capitais é assegurada de acordo com as disposições dos Tratados”. Disponível em: <http://eurlex.europa.eu/legal-content/PT/TXT/PDF/?uri=CELEX:12012E/TXT\&from=EN>. Acesso em: 21 jan. 2015.

${ }^{73}$ BARENTS, The Internal Market Unlimited: Some Observations on the Legal Basis..., p. 102-103.

${ }^{74}$ JAEGER JUNIOR, Liberdade de concorrência na União Europeia e no Mercosul, p. 134.

75 Caso Dióxido de Titânio, C-300/89, de 1991. Disponível em: <http://eur-lex.europa.eu/legalcontent/PT/TXT/?qid=1422934311197\&uri=CELEX:61989CJ0300>. Acesso em: 20 jan. 2015.

Cadernos do Programa de Pós-Graduação em Direito PPGDir./UFRgS | Edição Digital | Porto Alegre | Volume X | Número 3 | 2015 | P. 224-252
} 


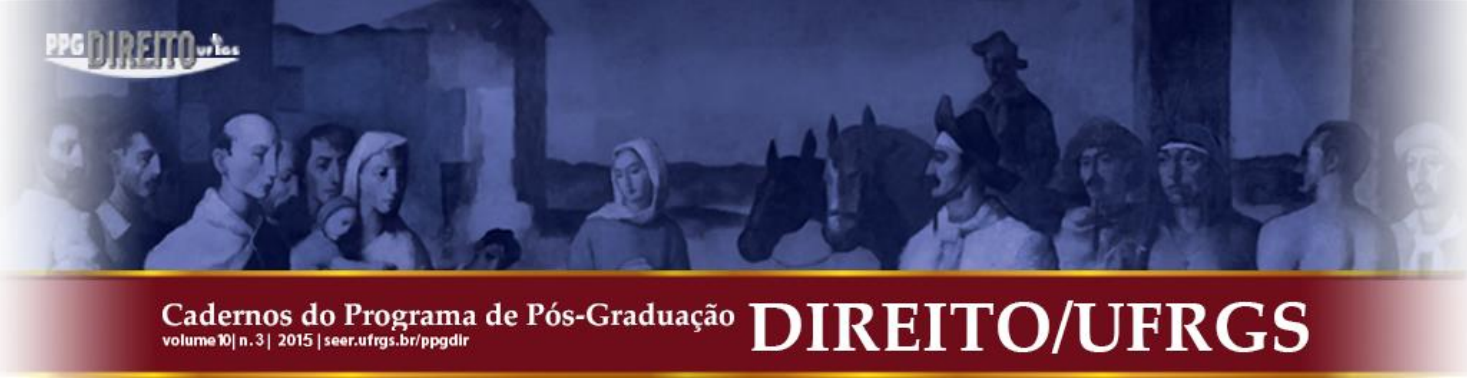

de concorrência, pois a deslocou da posição de norma apoiadora do mercado interno para o grau de elemento puro deste mercado como liberdade econômica fundamental ${ }^{76}$.

Cuida-se de um processo que invocava uma discussão acerca do sistema de harmonização de legislações na União Europeia, mediante a emissão de uma diretiva de aproximação. Salienta-se que as diretivas comunitárias são o principal meio normativo de harmonização legislativa do bloco, porquanto voltadas diretamente à atuação dos Estadosmembros, vinculando-os apenas quanto ao resultado pretendido, sem estabelecer a forma e os meios de obtenção, de modo a preservar a liberdade das instâncias nacionais ${ }^{77}$.

Apresentado ao Tribunal pela ex-Comissão das Comunidades Europeias, apoiada pelo Parlamento Europeu, o caso pretendia uma decisão em desfavor do ex-Conselho das Comunidades Europeias, tendo sido julgado sob o número C-300/89, em 11 de junho de $1991^{78}$. A demanda foi apresentada mediante petição apresentada à Secretaria do Tribunal de Justiça em 28 de setembro de 1989 pela Comissão.

Na espécie, pugnava-se pela anulação da Diretiva 89/428/CEE do Conselho, que estabelecia regras de harmonização dos programas de redução, tendo em vista a sua eliminação, da poluição causada por resíduos provenientes da indústria do dióxido de titânio. A diretiva adotada por unanimidade pelo Conselho com base no atual artigo 192 do TFUE visava, também, a melhorar as condições de concorrência na indústria do dióxido de titânio ${ }^{79}$, ao impor uma proibição total relativa a determinados resíduos provenientes desta indústria, bem como, fixava valores máximos de substâncias nocivas para outros resíduos de instalações existentes.

Sobre o tema, é importante destacar que a proteção da liberdade de concorrência mediante uma diretiva que regule o meio ambiente ocorre em virtude de que a existência de regras nacionais distintas para os padrões de proteção do meio ambiente possui como consequência imediata a deturpação da concorrência no mercado ${ }^{80}$. As empresas situadas em

\footnotetext{
${ }^{76}$ JAEGER JUNIOR, Mercados Comum e Interno e Liberdades Econômicas Fundamentais, p. 451.

${ }^{77}$ LIMPENS, Anne. Harmonisation des législations dans le cadre du maché commum. Revue Internationale de Droit Comparé, Paris, v. 19, n. 3, jul.-set. 1967, p. 638; É possível, em virtude da vinculação ao resultado, a responsabilização dos Estados pela a adequada transposição das diretivas, conforme observado nos casos Andrea Francovich e Danila Bonifaci e outros contra a República Italiana, casos apensos 6/90 e 9/90, nos quais o TJCE se manifestou sobre o tema. Processos apensos C-6/90 e C-9/90, Acórdão de 19 de novembro de 1991. Disponíveis em: <http://eur-lex.europa.eu/legal-content/EN/TXT/?uri=C ELEX:61990CJ0006>. Acesso em: 20 jan. 2015.

${ }^{78}$ Caso Dióxido de Titânio, C-300/89, de 1991.

${ }^{79}$ Caso Dióxido de Titânio, C-300/89, de 1991, parágrafos 1/2.

${ }^{80}$ Ver: JAEGER JUNIOR, Augusto. Concorrência e Meio Ambiente/Competition and the Environment. Cadernos do Programa de Pós-Graduação em Direito PPGDir./UFRGS, Porto Alegre, v. 1, n. 6, set. 2006. p. 43-48. 


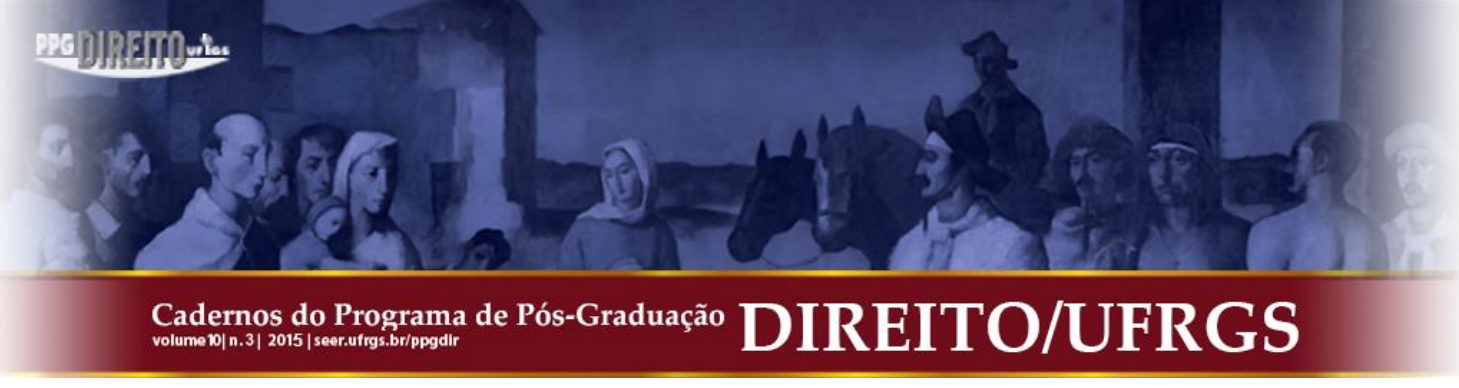

um Estado-membro que possui normas ambientais mais rígidas ficam em desvantagem competitiva em relação àquelas que estão situadas em territórios com legislação mais branda ${ }^{81}$.

A supracitada diretiva provém de uma proposta de 18 de abril de 1983 da Comissão, que se apoiava no atual artigo 114 do $\mathrm{TFUE}^{82}$, tendo esta sofrido uma alteração em 24 e 25 de novembro de 1988, na qual o Conselho adotou uma orientação comum baseando a diretiva no atual artigo 192 do TFUE ${ }^{83}$.

Isso significa dizer que no primeiro caso, conforme o artigo 114 do TFUE, o Conselho decidiria sobre proposta da Comissão, em cooperação com o Parlamento, em um processo bastante democrático. Na segunda hipótese, conforme o artigo 192 do TFUE, o Conselho decidiria por unanimidade, da mesma forma sob a proposta da Comissão, mas com mera oitiva do parlamento, em um processo menos democrático.

Ocorre que a Diretiva 89/428/CEE foi proposta pelo Conselho das Comunidades Europeias, atual Conselho da União Europeia, em 08 de junho de 1989, conforme as alterações do Ato Único Europeu, apoiada na regra do atual artigo 192 do TFUE, relacionada à proteção do meio ambiente. À época, a Comissão havia sugerido que a regra de harmonização aplicável era do atual artigo 114 do TFUE, tendo em vista que esta era destinada à uniformização das condições da concorrência, ou seja, a diretiva tinha por objeto o estabelecimento e funcionamento do mercado interno.

Com a decisão de adoção da norma do artigo 192 do TFUE para fundamentar a mencionada diretiva, o Parlamento Europeu foi escutado, em posição contrária à emissão da diretiva pelo Conselho e a favor da interpretação da Comissão, segundo a qual a diretiva deveria ser baseada no artigo 114 do TFUE, isto é, deveria ter sido editada pelo Parlamento Europeu e

\footnotetext{
${ }^{81}$ Id., Liberdade de concorrência na União Europeia e no Mercosul, p. 225.

82 “Art. 114.1. (ex-Artigo 95 do TCE). (...) O Parlamento Europeu e o Conselho, deliberando de acordo com o processo legislativo ordinário, e após consulta do Comité Económico e Social, adotam as medidas relativas à aproximação das disposições legislativas, regulamentares e administrativas dos Estados-Membros, que tenham por objeto o estabelecimento e o funcionamento do mercado interno" (grifo nosso). UNIÃO EUROPEIA. Tratado Sobre o Funcionamento da União Europeia (Versão Consolidada). Disponível em: <http://eurlex.europa.eu/lega/ content/PT/TXT/HTML/?uri= CELEX:12012E/TXT\&from=EN>. Acesso em: 20 jan. 2015.

83 “Artigo 192 do TFUE (ex-artigo 175.o TCE): O Parlamento Europeu e o Conselho, deliberando de acordo com o processo legislativo ordinário e após consulta ao Comité Económico e Social e ao Comité das Regiões, adotarão as ações a empreender pela União para realizar os objetivos previstos no artigo 191. (...) O Conselho, deliberando por unanimidade, sob proposta da Comissão e após consulta ao Parlamento Europeu, ao Comité Económico e Social e ao Comité das Regiões, pode tornar o processo legislativo ordinário aplicável aos domínios a que se refere o primeiro parágrafo. (...)" (Grifo nosso). UNIÃO EUROPEIA. Tratado Sobre o Funcionamento da União Europeia (Versão Consolidada). Disponível em: <http://eurlex.europa.eu/lega/content/PT/TXT/HTML/?uri= CELEX:12012E/TXT\&from=EN>. Acesso em: 20 jan. 2015.
} 


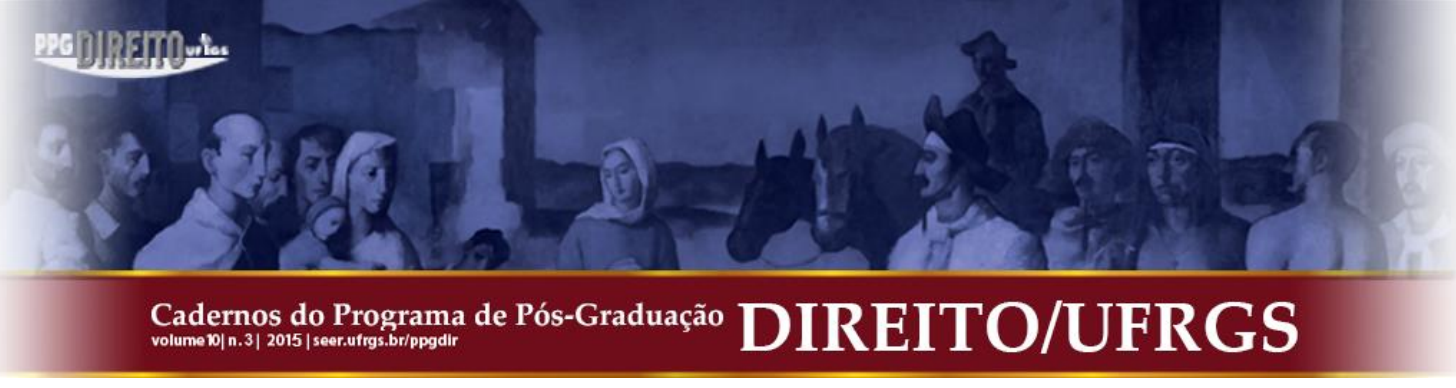

pela Comissão, em um processo mais democrático. Entretanto, apesar da objeção manifesta do Parlamento, baseada no princípio democrático ${ }^{84}$, o Conselho editou a diretiva.

O ponto central da discussão, no caso, era determinar qual regra a ser utilizada como norma autorizadora quando a diretiva buscasse mais de um objetivo (meio ambiente e a concorrência), com regulação em diferentes normas do Tratado, nos artigos 114 e 192 do TFUE. Cumpre salientar que esses objetivos, segundo o acórdão do Tribunal de Justiça, são indissociáveis e perseguidos com a mesma intensidade ${ }^{85}$. A Comissão sustentava que a proposta feita pelo Conselho estava eivada de nulidade porquanto equivocadamente fundamentada, tendo em vista que perseguia a harmonização das normas relacionadas ao direito da concorrência. Em conjunto a ela, o Parlamento Europeu clamava por uma maior participação no processo de elaboração da diretiva. Por outro lado, o Conselho, órgão que editou a diretiva, sustentava ter fundamentado a norma de forma condizente, pois o ponto central era a harmonização de normas sobre o meio ambiente.

Na decisão, o Tribunal entendeu que os órgãos não são livres para a escolha do fundamento autorizador de uma diretiva, devendo ater-se ao processo determinado pelo Tratado, ou seja, a escolha não é realizada conforme o convencimento do órgão sobre o objetivo. Sendo assim, dispôs que o reforço do objetivo da proteção do meio ambiente não é exclusivo do artigo 192 do TFUE, colocando que o envolvimento do Parlamento no processo de elaboração da diretiva, isto é, no processo de formação da vontade da União, culmina em uma preservação do princípio democrático fundamental, segundo o qual os povos participam no exercício do poder por intermédio de uma assembleia representativa.

Foi decidido pelo Tribunal que o mercado interno na União Europeia possui como requisito fundamental a existência de um sistema de concorrência não falseado, determinandose, em função disso, que as medidas de aproximação devem ser tomadas sob fundamento próprio, que consiste no artigo 114 do $\mathrm{TFUE}^{86}$. A diretiva foi anulada e se concluiu pela adoção de uma ampla interpretação do mercado interno conforme a teoria da ampliação, de modo que este abrange mais que o mercado comum ${ }^{87}$. Dessa forma, foi considerado adequado o uso de

\footnotetext{
${ }^{84}$ A defesa do princípio democrático decorre do fato de o parlamento europeu ser constituído de candidatos eleitos pelos cidadãos da União Europeia, mediante uma divisão de cadeiras proporcional. Assim, os cidadãos e as cidadãs estão diretamente representados pelo Parlamento Europeu, de modo que um projeto de aproximação legislativa votado por um órgão eleito pelo podo torna-se mais democrático.

${ }^{85}$ Caso Dióxido de Titânio, C-300/89, de 1991, parágrafo 13.

${ }^{86}$ Caso Dióxido de Titânio, C-300/89, parágrafo 14.

${ }^{87}$ BARENTS, The Internal Market Unlimited: Some Observations on the Legal Basis..., p. 94-96. 


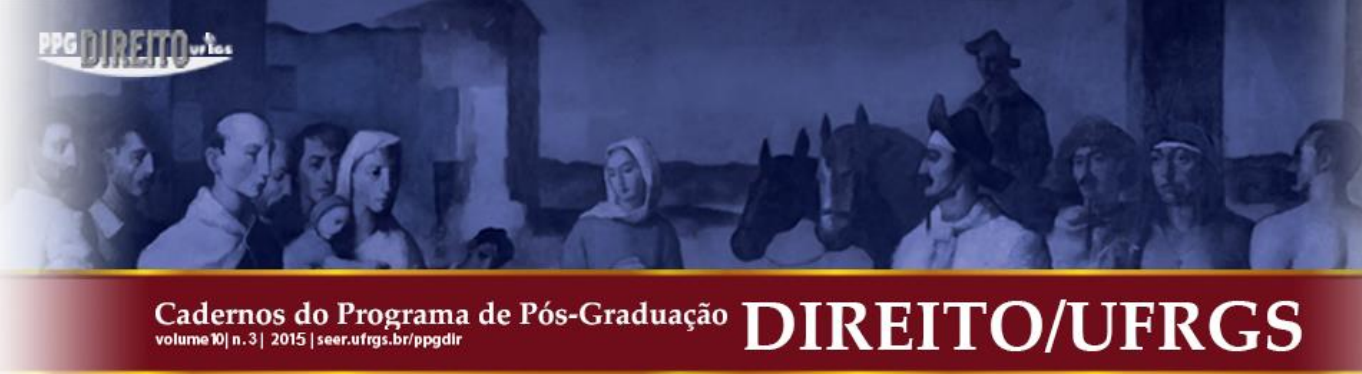

uma regra relativa ao mercado interno para a disciplina concorrencial e foi comprovada a elementaridade da liberdade de concorrência para o correto funcionamento do projeto de integração na União Europeia.

Conforme a interpretação adotada pelo Tribunal, é possível concluir que o mercado interno pressupõe que estejam presentes as quatro liberdades de circulação, acrescidas de um regime de concorrência não falseado ${ }^{88}$. Ademais, a decisão do Caso Dióxido de Titânio, segundo o doutrinador Augusto Jaeger Junior, permite o aprofundamento destas reflexões, tendo em vista que:

\begin{abstract}
Não apenas o fato de a concorrência ser parte ou não do mercado interno se mostra como resultado, mas também é possível depreender uma nova classificação para ela. Dióxido de Titânio pode ter desclassificado a concorrência como mera norma apoiadora, como mero meio para a realização do mercado interno, e tê-la classificado como elemento puro deste, isto é, como liberdade fundamental, tamanho o esforço argumentativo que foi promovido ${ }^{89}$.
\end{abstract}

Foi mediante a introdução da defesa da concorrência no mercado interno, na condição de liberdade econômica fundamental, que o Tribunal acabou por reconhecer, de forma contundente, que esta é a pedra angular do processo de integração europeu.

\title{
2.2 Casos TeliaSonera (C-52/09) e Comissão c. Italia (C-496/09)
}

Após o reconhecimento da liberdade de concorrência pela jurisprudência do Tribunal de Luxemburgo como parte integrante do rol das liberdades econômicas fundamentais a conformarem o mercado interno na União Europeia, conforme o julgamento do Caso Dióxido de Titânio de 1991, foram identificadas severas críticas à ampliação do referido conceito por parte da doutrina ${ }^{90}$. Entretanto, insta afirmar que a decisão encontra-se perfeitamente alinhada ao sistema jurídico previsto pelos Tratados da União na formação de uma verdadeira arquitetura jurídica europeia ${ }^{91}$.

Nos termos do disposto por Giuseppe Tesauro, o sistema do mercado interno é composto por regras que possuem a finalidade de liberar o comércio de mercadorias e o movimento de

\footnotetext{
${ }^{88}$ Ibid., p. 104-105.

89 JAEGER JUNIOR, Liberdade de concorrência na União Europeia e no Mercosul, p. 236.

${ }^{90} \mathrm{O}$ doutrinador Rene Barents apresenta a existência das críticas, porém não compartilha delas. BARENTS, The Internal Market Unlimited: Some Observations on the Legal Basis of Community Legislation, p. 96.

${ }^{91}$ Ibid., p. 96.

Cadernos do Programa de Pós-Graduação em Direito PPGDir./UFRGS | Edição Digital | Porto Alegre | Volume X | Número 3 | 2015 | P. 224 - 252
} 


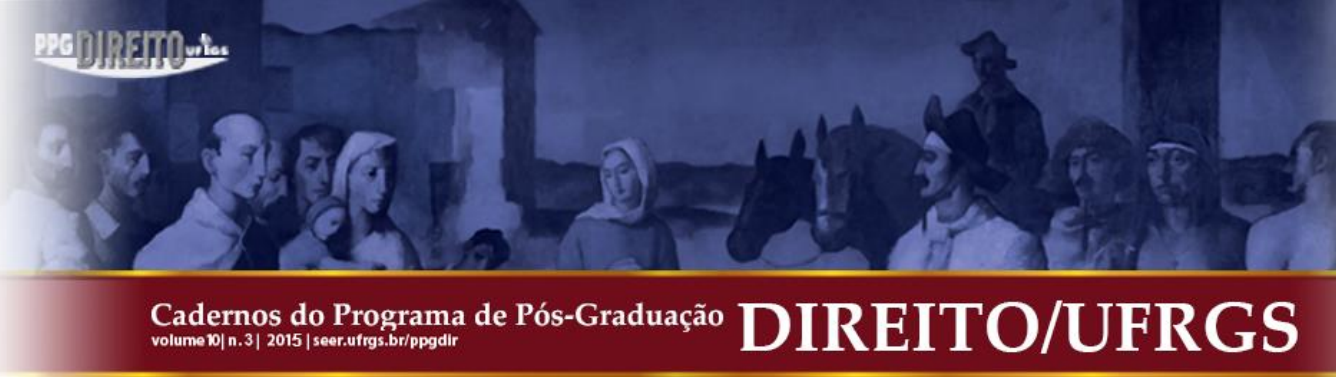

foi alterado o seu status jurídico ${ }^{97}$, garantindo-se a manutenção da proteção jurídica à liberdade de concorrência na União Europeia ${ }^{98}$.

Todos esses fatores poderiam ter operado modificações no sistema de reconhecimento da liberdade de concorrência, ou, ainda, alterado o entendimento do Tribunal de Justiça da União Europeia já conquistado pelo acórdão do Caso Dióxido de Titânio. Entretanto, concretamente, não foi este o ocorrido.

Juridicamente, com a entrada em vigor dos Regulamentos 1/2003 e 139/200499, foi verificada uma aproximação paulatina do direito da concorrência ao sistema das demais liberdades econômicas fundamentais, tendo em vista que estes preveem uma aplicabilidade imediata ao artigo 101 do TFUE ${ }^{100}$. Segundo o doutrinador Augusto Jaeger Junior, isto "significou para elas uma igualdade com as normas das liberdades fundamentais na questão de poderem ser aplicadas pelos Estados-membros e invocadas por particulares"101.

A jurisprudência mantém-se firme no reconhecimento do papel ocupado pela liberdade de concorrência no mercado interno, já consagrado como fulcral ao processo de integração econômica. Duas decisões recentes do Tribunal de Justiça da União Europeia trazem luz a essa colocação.

A primeira delas foi proferida no Caso TeliaSonera, em 17 de fevereiro de $2011^{102}$, conforme pedido de decisão prejudicial apresentado pelo Stockholms tingsrätt (Tribunal de Primeira Instância de Estocolmo, na Suécia) ao Tribunal de Justiça da União Europeia, com uma série de dez questões sobre a interpretação do artigo 102 do TFUE, relativas a um alegado abuso de posição dominante sob a forma de compressão de margens.

O pedido foi apresentado no âmbito de um litígio entre Konkurrensverket, autoridade sueca da concorrência, e TeliaSonera Sverige $A B$, empresa que fornecia serviços de telefonia e internet na Suécia. A referida autoridade apresentou uma requisição no sentido de que a empresa de telefonia fosse condenada a pagar uma indenização por ter violado as normas

\footnotetext{
97 VON ROMPUY, Ben. The Impact of the Lisbon Treaty on EU Competition Law: A Review of Recent Case Law of the EU Courts. Competition Policy International Antitrust Chronicle. Disponível em: <http://papers.ssrn.com/sol3/papers.cfm?abstract_id=1970081>. Acesso em: 10 set. 2014.

98 JAEGER JUNIOR, Mercados Comum e Interno e Liberdades Econômicas Fundamentais, p. 451.

${ }^{99}$ Sobre o tema, ver: CRAIG; DE BÚRCA, EU law: text, cases, and materials, p. 1045-1067.

${ }^{100}$ JAEGER JUNIOR, op. cit., p. 252.

101 Ibid., p. 252.

102 Caso Konkurrensverket c. TeliaSonera Sverige AB (C-52-09), de 2011. Disponível em: < http://curia.europa.eu/juris/document/document.jsf?text=\&docid=81796\&pageIndex=0\&doclang=PT\&mode=1st $\&$ dir $=\&$ occ $=$ first $\&$ part=1\&cid=165753> . Acesso em: 20 jan. 2015.

Cadernos do Programa de Pós-Graduação em Direito PPGDir./UFRGS | Edição Digital | Porto Alegre | Volume X | Número 3 | 2015 | P. 224-252
} 


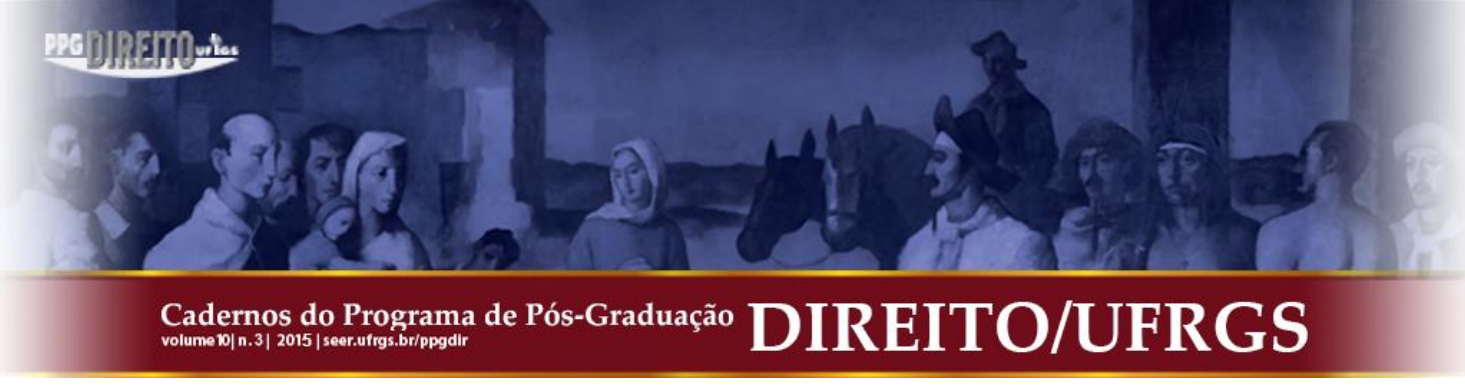

nacionais e o TFUE. Conforme o teor da decisão foi mantida a interpretação de que o mercado interno abrange a liberdade de concorrência, mediante a interpretação literal das normas contidas nos Tratados fundacionais da União ${ }^{103}$.

A segunda decisão foi proferida no Caso Comissão Europeia c. República Italiana, em 17 de novembro de $2011^{104}$, baseado em uma ação por incumprimento intentada pela Comissão contra a Itália. Inicialmente, no ano de 1999, a Comissão Europeia adotou uma decisão considerando que parte de um auxílio concedido pela Itália para promover o emprego violou as regras comunitárias relativas aos auxílios estatais e solicitando a recuperação dos montantes concedidos ilegalmente. Em 2004, o Tribunal declarou que a Itália, ao não adotar no prazo fixado as medidas necessárias para recuperar o auxílio, não cumpriu as obrigações da decisão.

No acórdão proferido em 2011, o Tribunal de Justiça da União Europeia confirmou que a Itália, por não ter realizado a recuperação dos auxílios estatais concedidos ilegalmente dos seus beneficiários, não cumpriu a decisão anterior. Na determinação do montante da sanção pecuniária compulsória proporcional à infração, o Tribunal sublinhou a natureza vital das disposições do TFUE em matéria de concorrência. Ademais, foi reconhecido que o TUE, mediante o seu artigo $3^{\circ}, n^{\circ} 3$, estabelece um mercado interno ${ }^{105}$, que pressupõe um sistema em que a concorrência não seja falseada. Sendo assim, dispôs-se que a defesa da concorrência tem por finalidade evitar que esta seja falseada em detrimento do interesse geral, das empresas individuais e dos consumidores, contribuindo ao mercado interno, conforme segue:

(...) importa recordar o carácter fundamental das disposições do Tratado em matéria de concorrência e, muito particularmente, as relativas aos auxílios de Estado, que constituem a expressão de uma das missões essenciais conferidas à União Europeia. (...) este carácter fundamental resulta do artigo $3 .^{\circ}$, n. ${ }^{\circ} 3$, TUE, designadamente do estabelecimento do mercado interno, e do Protocolo n. ${ }^{\circ} 27$ relativo ao mercado interno e à concorrência, o qual, ao abrigo do artigo 51. ${ }^{\circ}$ TUE, faz parte integrante dos Tratados, e nos termos do qual o mercado interno inclui um sistema que assegura que a concorrência não seja falseada ${ }^{106}$.

\footnotetext{
${ }^{103}$ Caso Konkurrensverket c. TeliaSonera Sverige AB (C-52-09), de 2011.

104 Caso Comissão Europeia c. República Italiana (C-496-09), de 2011. Disponível em: <http://eurlex.europa.eu/legal-content/PT/TXT/PDF/?uri=CELEX:62009CJ0496\&from=PT>. Acesso em: 20 jan. 2015.

105 “Artigo 3.o (...) 3. A União estabelece um mercado interno. Empenha-se no desenvolvimento sustentável da Europa, assente num crescimento económico equilibrado e na estabilidade dos preços, numa economia social de mercado altamente competitiva que tenha como meta o pleno emprego e o progresso social, e num elevado nível de proteção e de melhoramento da qualidade do ambiente. A União fomenta o progresso científico e tecnológico. (...)". UNIÃO EUROPEIA. Tratado da União Europeia (Versão Consolidada). Disponível em: <http://eurlex.europa.eu/legal-content/PT/TXT/PDF/?uri=CELEX:12012M /TXT\&from=EN>. Acesso em: 20 jan. 2015.

106 Caso Comissão Europeia c. República Italiana (C-496-09), de 2011, parágrafo 60. 


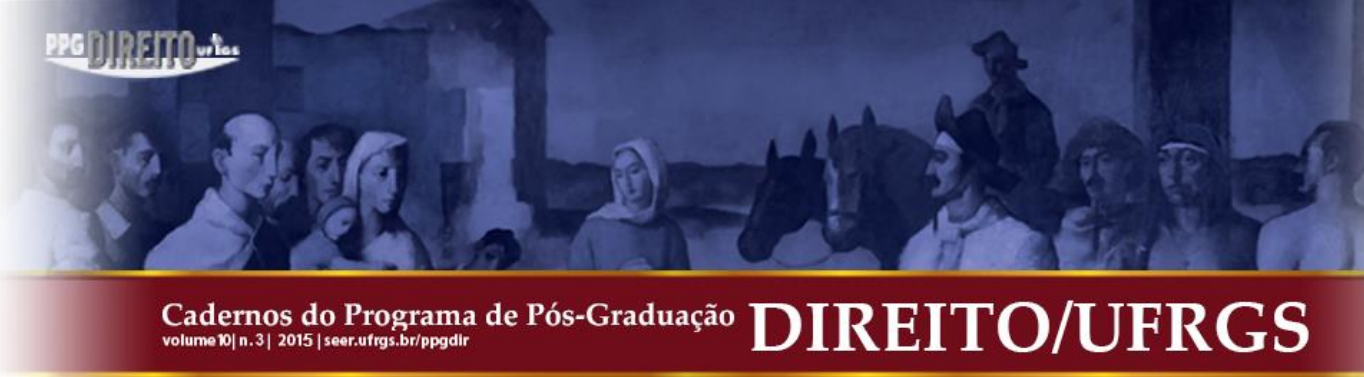

Sendo assim, foi reafirmada a importância das regras do Tratado em matéria de concorrência como disposições fundamentais ao mercado interno e à integração econômica. Como tal, passa a liberdade de concorrência a ser novamente reconhecida como pedra angular na União Europeia.

Como conclusão parcial da segunda parte deste estudo, afirma-se que a jurisprudência do Tribunal de Justiça da União Europeia reconhece a importância do direito concorrencial para a consecução dos objetivos da União Europeia e para a consolidação do processo de integração, consagrando seu papel de liberdade econômica fundamental a embasar o mercado interno.

\section{CONSIDERAÇÕES FINAIS}

O direito da concorrência é aquele que protege o exercício da liberdade de concorrência, definido como o conjunto de regras mínimas para a organização da esfera privada para a promoção de maiores possibilidades de escolha aos agentes atuantes em um mercado. Ocorre que na União Europeia, a concorrência ultrapassa o mero aspecto regulatório ao ser reconhecida como uma liberdade econômica fundamental, devendo atuar ao lado das quatro demais liberdades, que consistem na circulação de mercadorias, de pessoas, de serviços e de capitais.

O capítulo do TFUE referente ao direito da concorrência possui o condão de organizar a disciplina no espaço comunitário, mediante os seus artigos 101 a 109, núcleo da regulamentação da União Europeia na matéria. Cumpre destacar a importância da previsão da liberdade de concorrência como norma essencial ao mercado interno, conforme interpretação do artigo $3^{\circ}$ do Tratado da União Europeia. Ademais, salienta-se a sua consolidação no âmbito supranacional mediante o estabelecimento de uma concorrência praticável no quadro de um mercado comunitário tradicionalmente pouco concorrencial.

Sobre os casos analisados, ressalta-se que o Tribunal de Justiça da União Europeia vela pela interpretação uniforme do direito da concorrência em todos os países do bloco e pelo reconhecimento da liberdade de concorrência como elemento a embasar o mercado interno, conforme demonstrado pelas decisões proferidas em Dióxido de Titânio (1991) Konkurrensverket v TeliaSonera Sverige AB (2011) e Comissão v. Republica Italiana (2011). 


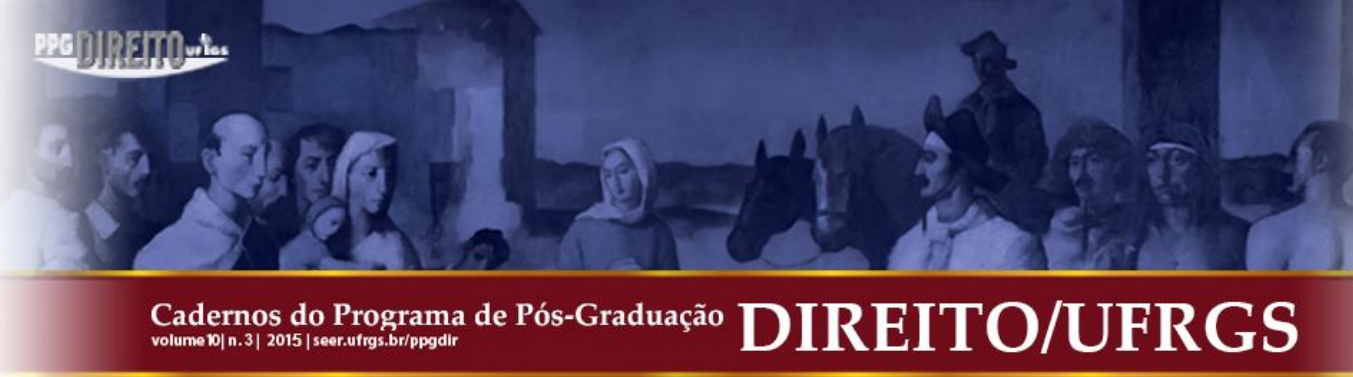

Chega-se, então, à resposta para a pergunta de pesquisa apresentada no início deste estudo, que era: qual a relação entre a liberdade de concorrência e o mercado interno na União Europeia? A doutrina sobre direito da integração e da concorrência adotada como marco teórico do estudo, bem como a jurisprudência do Tribunal de Justiça da União Europeia apresentada, reconhecem à liberdade de concorrência um caráter de essencialidade para a realização do processo de integração, servindo como base para o mercado interno na condição de liberdade econômica fundamental.

O processo de evolução das regras de concorrência é elementar na modificação das estruturas de mercado por amparar a integração europeia. É nesse âmbito que a liberdade de concorrência assume grande importância independentemente da geração ou não de efeitos econômicos, justamente ao garantir e amparar as demais liberdades essenciais para o desenvolvimento do processo de integração.

Com base no estudo proposto, conclui-se que a liberdade de concorrência, na condição de liberdade econômica fundamental, foi substantiva para a criação e para o fortalecimento do mercado interno na União Europeia enquanto instituição. Assim, conforme a construção jurídica apresentada ao longo do trabalho, por meio da análise doutrinária e jurisprudencial, constata-se que a liberdade concorrencial representa elemento essencial à existência do mercado interno no âmbito da União Europeia.

\section{REFERÊNCIAS}

ALMEIDA, Elizabeth Accioly Pinto de. Mercosul e União Européia: estrutura jurídicoinstitucional. Curitiba: Juruá, 1996. 159 p.

ALVES, Jorge de Jesus Ferreira. Direito da Concorrência nas Comunidades Europeias. 2. ed. Coimbra: Coimbra Editora, 1992. 361 p.

AYRAL, Michel. Le marché intérieur de l'Union européenne: Les règles du jeu. Paris: Le documentation française, 1998. $183 \mathrm{p}$.

BALASSA, Bela. Teoria da Integração Económica. Lisboa: Clássica, 1961. 453 p. 


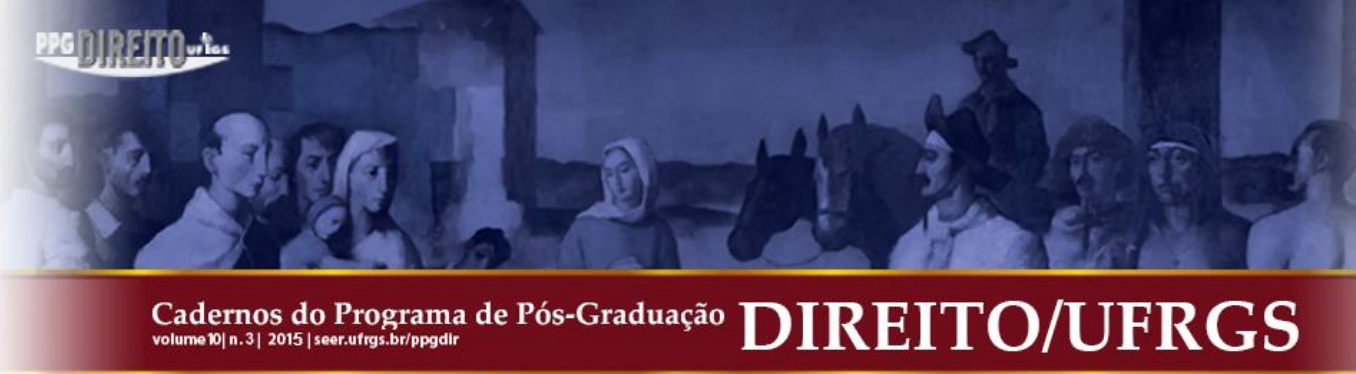

BARENTS, René. The Internal Market Unlimited: Some Observations on the Legal Basis of Community Legislation. Common Market Law Review, Londres, n. 30, v. 1, p. 85-109, 1993.

BASEDOW, Jürgen. The Modernization of European Competition Law: A Story of Unfinished Concepts. Texas International Law Journal, Austin, v. 42, n. 3, p. 429-439, 2007.

BERTONI, Liliana. La Libre Circulación y los Derechos Fundamentales en los procesos de integración Regional. In: MOLINA DEL POZO, Carlos (Coord.). Evolución histórica y jurídica de los procesos de integración en la Unión Europea y en el Mercosur: liber amicorum Miguel Ángel Ciuro Caldani. Buenos Aires: Eudeba, p. 99-111, 2011.

BORCHARDT, Klaus Dieter. The ABC of European Union Law. Luxembourg: Publications Office of the European Union, 2010. 32 p.

CAMPELLO, Dyle. O direito da concorrência no direito comunitário. Rio de Janeiro: Renovar, 2001. 352 p.

CAMPOS, João Mota de. Manual de Direito Comunitário. 2. ed. Curitiba: Juruá, 2008. 544 p.

CASELLA, Paulo Borba. Comunidade Européia e seu ordenamento jurídico. São Paulo: LTr, 1994. 648 p.

CELLI JUNIOR, Umberto. Regras de concorrência no Direito Internacional moderno. Porto Alegre: Livraria do Advogado, 1998. 252 p.

CRAIG, Paul; DE BÚRCA, Gráinne. EU law: text, cases, and materials. 4. ed. Oxford: Oxford University Press, 2007. 1284 p.

CUNHA, Ricardo Thomasinho da. Direito e Defesa da Concorrência: Mercosul e União Europeia. Barueri: Manole, 2003. 368 p.

DROMI, Roberto; EKMEKDJIAN, Miguel A.; RIVERA, Julio C. Derecho comunitario: sistemas de integracion, regimen del Mercosul. 2. ed. Buenos Aires: Ciudad Argentina, 1996. $671 \mathrm{p}$. 


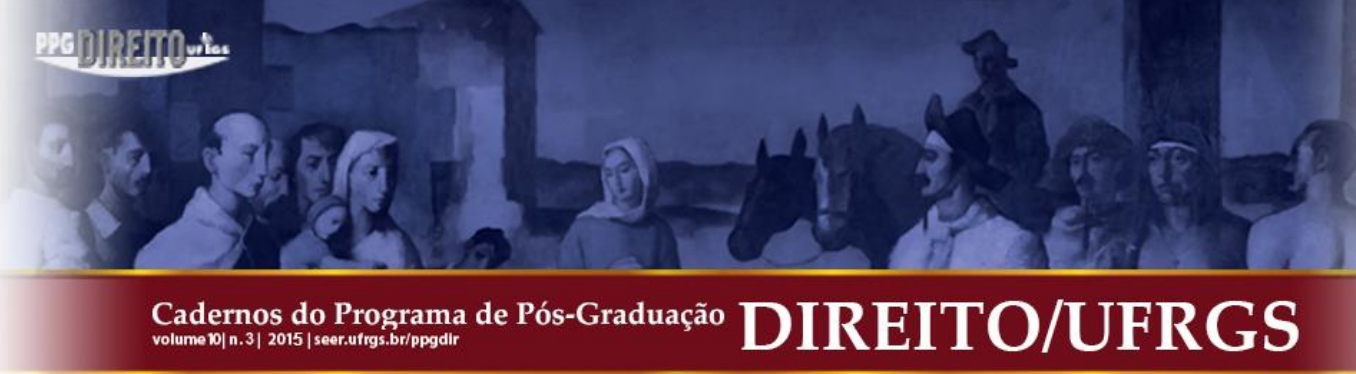

Juruá, 2010. 800 p.

. Mercados Comum e Interno e Liberdades Econômicas Fundamentais. Curitiba:

. Metodologia jurídica europeia e mercosulista: considerações fundamentais. Revista da Secretaria do Tribunal Permanente de Revisão do Mercosul, Assunção, n. 3, p. 117 157, mar. 2014.

JAEGER JUNIOR, Augusto; NORDMEIER, Carl Friedrich. Novidades na regulamentação das ajudas públicas do direito comunitário da concorrência. Revista de Direito da Concorrência. Brasília, v. 1, n. 22, p. 11-64, abr. 2010.

LIMPENS, Anne. Harmonisation des législations dans le cadre du maché commum. Revue Internationale de Droit Comparé, Paris, v. 19, n. 3, p. 621-653, jul.-set. 1967.

MARQUES, Frederico do Valle Magalhães. Direito Internacional da Concorrência. Rio de Janeiro: Renovar, 2006. 512 p.

MOLINA DEL POZO, Carlos Francisco. Manual de derecho de la comunidade europeia. 3.ed. Madrid: Trivium, 1997. 953 p.

. Breve historia de la construcción europea a través de los tratados. In: MOLINA DEL POZO, Carlos (Coord.). Evolución histórica y jurídica de los procesos de integración en la Unión Europea y en el Mercosur: liber amicorum Miguel Ángel Ciuro Caldani. Buenos Aires: Eudeba, 2011. p. 247-296.

MUNHOZ, Carolina Pancotto Bohrer. Direito, livre concorrência e desenvolvimento. São Paulo: Lex Editora, 2006. 266 p.

NUSDEO, Ana Maria de Oliveira. Defesa da Concorrência e Globalização Econômica: o controle da concentração de empresas. São Paulo: Malheiros, 2002. 290 p.

OLIVEIRA, Gesner; RODAS, João Grandino. Direito e economia da concorrência. 2. ed. rev. e atual. São Paulo: Revista dos Tribunais, 2013. 495 p.

PESCATORE, Pierre. Derecho de la integración: nuevo fenómeno en las relaciones internacionales. Buenos Aires: Intal, 1973. 105 p. 


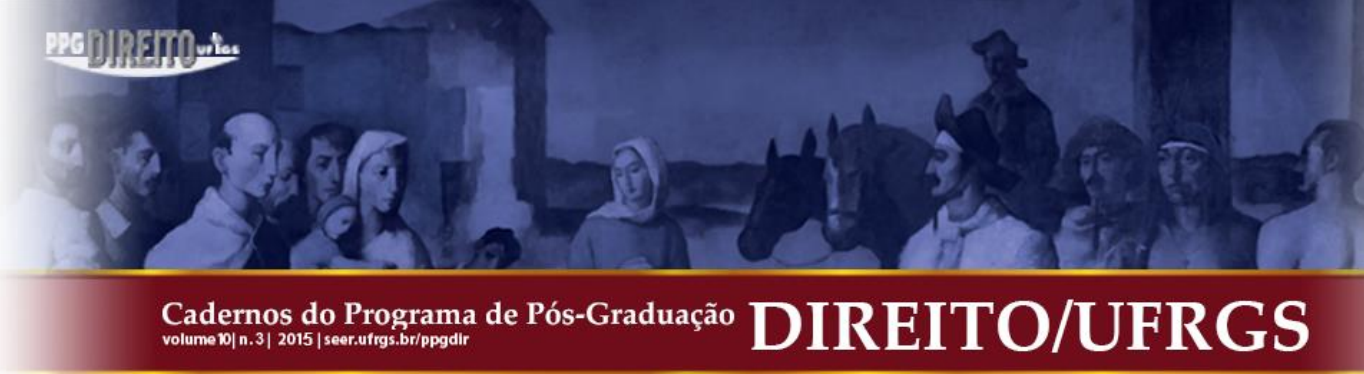

ROSSI, Lucia Serena. Il buon funzionamento del mercato comune: delimitazione dei poteri fra CEE e stati membri. Milano: Giuffrè Editore, 1990. 231 p.

RUÍZ DÍAZ LABRANO, Roberto. La integración y las constituiciones nacionales de los Estados Parte del Mercosur. Anuario de Derecho Constitucional Latinoamericano. Buenos Aires: CIEDLA, Konrad-Adenauer-Stiftung, p. 65-78, 1999.

SALOMÃO FILHO, Calix to. Direito Concorrencial. São Paulo: Malheiros, 2013. 632 p.

SCHULTES, Marcelo. O Controle Concorrencial: Regulador do Mercado Interno na União Europeia. Revista Cadernos do Programa de Pós-Graduação em Direito PPGDir/UFRGS. Porto Alegre, v. 9, n. 1, p. 12, ago. 2014.

SILVA, Valéria Guimarães de Lima e Silva. Direito Antitruste: Aspectos Internacionais. Curitiba: Juruá, 2006. 528 p.

TESAURO, Giuseppe. The Community's Internal Market in the light of the Recent Case-Law of the Court of Justice. Yearbook of European Law, Oxford, v. 15, n. 1, p. 1-16, 1995.

UNIÃO EUROPEIA. Tratado sobre o Funcionamento da União Europeia (Versão Consolidada). Disponível em: <http://eur-lex.europa.eu/legal-content/PT/TXT/PDF/?uri=CE LEX:12012E/TXT\&from=EN>. Acesso em: 15 jan. 2015.

UNIÃO EUROPEIA. Tratado da União Europeia (Versão Consolidada). Disponível em: <http://eur-lex.europa.eu/legal-content/PT/TXT/PDF/?uri=CELEX:12012M $/ T X T \&$ from $=\mathrm{EN}>$. Acesso em: 15 jan. 2015.

VON ROMPUY, Ben. The Impact of the Lisbon Treaty on EU Competition Law: A Review of Recent Case Law of the EU Courts. Competition Policy International Antitrust Chronicle. Disponível em: <http://papers.ssrn.com/sol3/papers.cfm?abstract_id=1970081〉. Acesso em: 10 jan. 2015. 


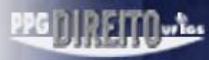

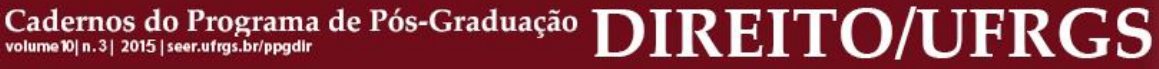

Submissão: 19/03/2015

Aceito para Publicação: 03/12/2015 
